\title{
Composition, Alteration, and Texture of Fault-Related Rocks from Safod Core and Surface Outcrop Analogs: Evidence for Deformation Processes and Fluid-Rock Interactions
}

\author{
Kelly K. Bradbury, ${ }^{1}$ Colter R. Davis, ${ }^{1}$ John W. Shervais, ${ }^{1}$ Susanne U. Janecke, ${ }^{1}$ and James P. Evans ${ }^{1}$
}

\begin{abstract}
We examine the fine-scale variations in mineralogical composition, geochemical alteration, and texture of the faultrelated rocks from the Phase 3 whole-rock core sampled between 3,187.4 and 3,301.4 m measured depth within the San Andreas Fault Observatory at Depth (SAFOD) borehole near Parkfield, California. This work provides insight into the physical and chemical properties, structural architecture, and fluid-rock interactions associated with the actively deforming traces of the San Andreas Fault zone at depth. Exhumed outcrops within the SAF system comprised of serpentinitebearing protolith are examined for comparison at San Simeon, Goat Rock State Park, and Nelson Creek, California. In the Phase 3 SAFOD drillcore samples, the fault-related rocks consist of multiple juxtaposed lenses of sheared, foliated siltstone and shale with blockin-matrix fabric, black cataclasite to ultracataclasite, and sheared serpentinite-bearing, finely foliated fault gouge. Meters-wide zones of sheared rock and fault gouge correlate to the sites of active borehole casing deformation and are characterized by scaly clay fabric with multiple discrete slip surfaces or anastomosing shear zones that surround conglobulated or rounded clasts of compacted clay and/or serpentinite. The fine gouge matrix is composed of $\mathrm{Mg}$ rich clays and serpentine minerals (saponite \pm palygorskite, and lizardite \pm chrysotile). Whole-rock geochemistry data show increases in $\mathrm{Fe}-, \mathrm{Mg}-$, $\mathrm{Ni}$-, and $\mathrm{Cr}$-oxides and hydroxides, $\mathrm{Fe}-$-sulfides, and C-rich material, with a total organic content of $>1 \%$ locally in the fault-related rocks. The faults sampled in the field are composed of meters-thick zones of cohesive to non-cohesive, serpentinite-bearing foliated clay gouge and black fine-grained fault rock derived from sheared Franciscan Formation or serpentinized Coast Range Ophiolite. X-ray diffraction of outcrop samples shows that the foliated clay gouge is composed primarily of saponite and serpentinite, with localized increases in $\mathrm{Ni}$ - and $\mathrm{Cr}$-oxides and $\mathrm{C}$-rich material over several meters. Mesoscopic and microscopic textures and deformation mechanisms interpreted from the outcrop sites are remarkably similar to those observed in the SAFOD core. Microscale to meso-scale fabrics observed in the SAFOD core exhibit textural characteristics that are common in deformed serpentinites and are often attributed to aseismic deformation with episodic seismic slip. The mineralogy and whole-rock geochemistry results indicate that the fault zone experienced transient fluid-rock interactions with fluids of varying chemical composition, including evidence for highly reducing, hydrocarbon-bearing fluids.
\end{abstract}

1 Geology Department, Utah State University, Logan, UT 84322-4505, USA. E-mail: james.evans@usu.edu

\section{Introduction}

Well-constrained geological, geochemical, and geophysical models of active fault zones are needed if we are to understand fault zone behavior and earthquake deformation, constraining the factors that affect the distribution of earthquakes, and the nature of slip in the shallow crust by developing realistic models of subsurface fault zone structure and ground motion predictions. Earthquakes nucleate in rocks at depth (e.g., Fagereng and Toy 2011; Sibson 1977; 2003), yet until recently (see ANDO, 2001; Boullier et al. 2009; Cornet et al. 2004; Heermance et al. 2003; Hickman et al. 2004; HickMAN et al. 2007; Hirono et al. 2007; ОhtANi et al. 2000; TANAKA et al. 2002; Tobin and Kinoshita 2006; Townend et al. 2009; ZoВАСК et al. 2007; Zоваск et al. 2010), we have only had limited sampling of rocks or observations from within active plate-boundary fault zones where earthquake nucleation and rupture propagation has occurred. Direct knowledge of rock properties from active fault zones through integrated drilling, field, and laboratory studies can provide significant insight into fault processes, and can be used to: (1) identify systematic compositional and textural changes to infer the chemical and physical processes involved in fault zone evolution; (2) delineate the dimensions of the structural and permeability fault zone architecture; and (3) consider the role of fluid migration and fluidrelated alteration throughout deformation (BRODSKY et al. 2010; CAINE et al. 1996, 2010; Chester and Logan 1986; Cowan 1999; Evans and Chester 1995; FAGERENG and Sibson 2010; KNIPE et al. 1998; MARONE and Richardson 2010; Meneghini and Moore 2007; Rowe et al. 2009; SHIPTON AND Cowie and Cowie 2001; SibSON 1989; WibBERLEY et al. 2008). 
The San Andreas Fault Observatory at Depth (SAFOD; HicKMAN et al. 2004; HicKMAN et al. 2007; ZовАск et al. 2010; http://www.earthscope.org/ observatories/safod) near Parkfield, California, provides a nearly continuous record of rock cuttings and a limited amount of core from the subsurface through the Pacific Plate northeastward across the San Andreas Fault and into the North American Plate (Fig. 1). At SAFOD, in situ fault-related rocks from $\sim 3 \mathrm{~km}$ depth were sampled along the central creeping segment of the San Andreas Fault (SAF). The surface creep rate of the SAF near SAFOD is 20 $\mathrm{mm} / \mathrm{yr}$ (Titus et al. 2006), and is interpreted to occur on multiple parallel strands in the subsurface (HoLE et al. 2006; McPhee et al. 2004; ThURBer et al. 2004; ThURBer et al. 2006; Zоваск et al. 2005). Within the SAF here, a series of repeating microearthquakes occur near 2,500-2,800 m vertical depth, or about $\sim 50-300 \mathrm{~m}$ from the actively creeping fault strands intersected by the SAFOD borehole (Fig. 1; NADEAU et al. 2004; Thurber et al. 2004; Zоваск et al. 2010;
Zoback et al. 2011). Previous research by Bradbury et al. (2007), BRAdBuRy et al. (2011), HoldSwORTH et al. (2011), SPRINGER et al. (2007), and THAYER and Arrowsmith (2005) illustrate the geologic and structural setting and provide detailed core observations of the SAFOD site.

Serpentinite was identified in several SAFOD samples, between a depth of 3 and $4 \mathrm{~km}$ (BRADBURY et al. 2011; Moore and Rymer 2007; Moore and Rymer 2012; Solum et al. 2006; Phase 3 Core Photo Atlas, http://www.earthscope.org/observatories/ safod). This mineralogy and the associated alteration products may promote weak fault behavior (Hirth and Guillot 2013; Moore et al. 1997; Moore and RyMer 2012; REINEN et al. 2000; SCHLEICHER et al. 2012). In the two $\sim 1-2 \mathrm{~m}$ thick gouge zones associated with active creep demonstrated by borehole casing deformation at SAFOD, serpentinite and serpentinite-derived clays are present (Solum et al. 2006, 2007; Bradbury et al. 2011; Moore and Rymer 2009, 2012). The two zones, referred to as the

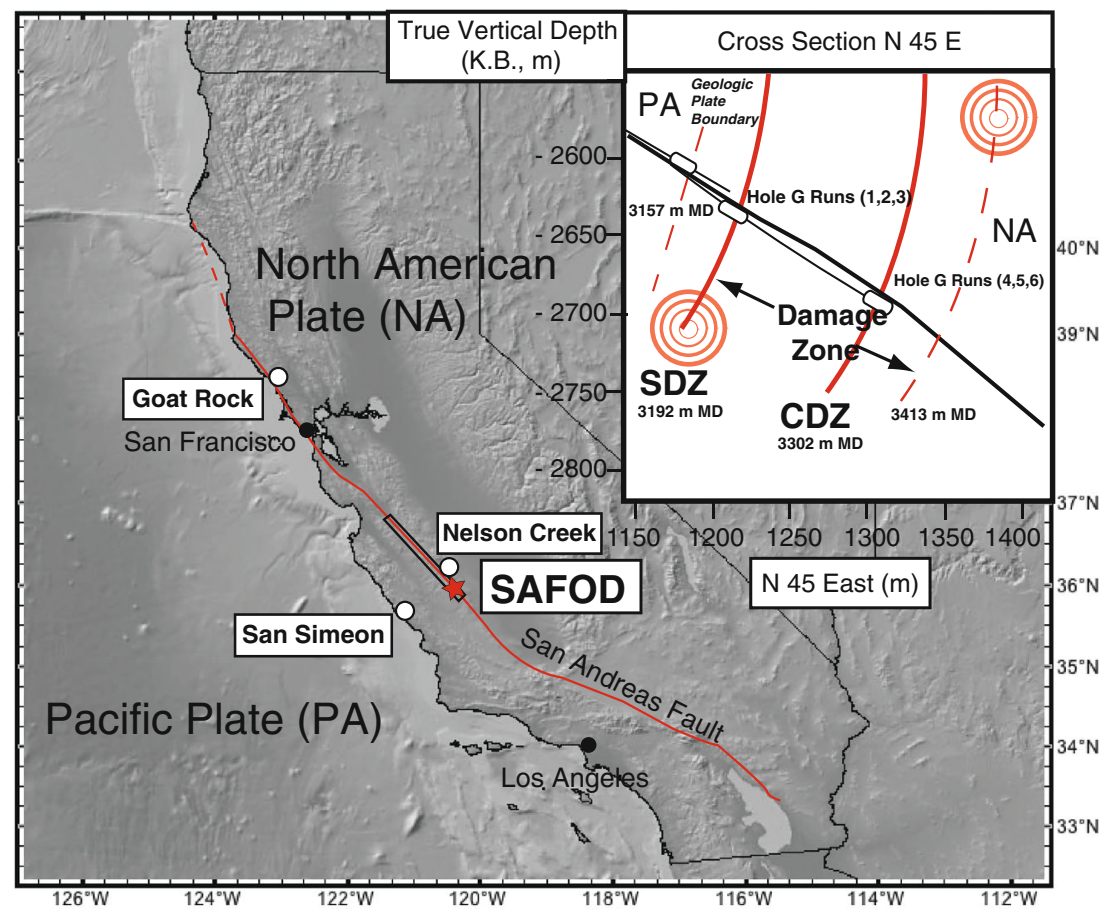

Figure 1

Location map of the SAFOD borehole and surface outcrops in California relative to the positions of the San Andreas Fault, Pacific Plate, and North American plate. The inset illustrates a simplified vertical profile of the SAFOD borehole, location of the targeted earthquakes, SDZ, CDZ, and the associated damage zone (JePPSON et al. 2010; ZовACK et al. 2010), and the Phase 3 core as sampled at depth (modified from Phase 3 Core Photo Atlas, http://www.earthscope.org) 

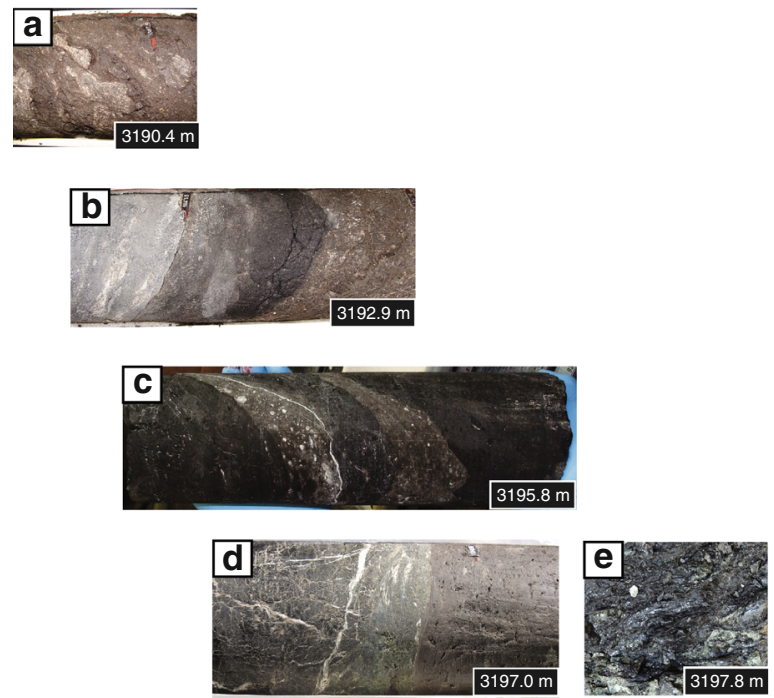

Black cataclasite to

Phyllosilicate-rich block-in-matrix melange ultracataclasite $S D Z$

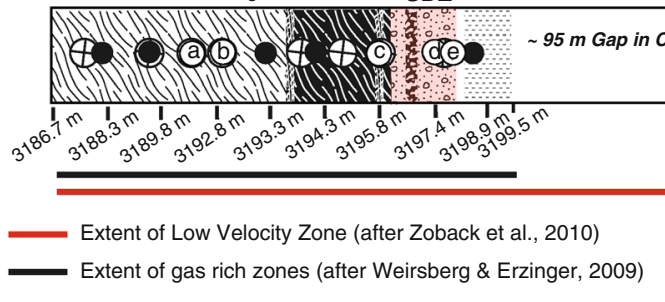

$\otimes$ Location of thin-section photomicrographs shown in Figures 4,5, and 7 and
whole-rock geochemical analyses shown in Figures $4 A$ \& 4B

Total Organic Carbon (TOC) sample results shown in Table 2

(b) Location of image shown above (may or may not correspond to sample location)

Figure 2

Mesoscopic textures of fault-related rocks in SAFOD Phase 3 core: a foliated block-in-matrix fabric within damaged rocks west of the SDZ; b localized black (carbon-rich) staining parallel to fracture surface at 3,192.9 m MD; c Black fault-related rock consists of cataclasite to ultracataclasite at 3,195.8 m MD; d serpentinite and scaly clay gouge of the SDZ at 3,197 m MD; e foliated fault gouge with scaly clay fabric at 3,197.8 m MD; f clay-rimmed altered serpentinite and siltstone clasts within foliated fault gouge of the CDZ at 3,297.5 m MD; g foliated fault gouge with scaly clay matrix and numerous rounded and lens-shaped, altered serpentinite clasts and fragments at 3,297.7 m $\mathrm{MD} ; \mathbf{h}$ block of intensely sheared siltstone with abundant calcite veinlets to the immediate northeast of the CDZ fault boundary; and i intensely sheared black clay (organic-rich?) interval with shiny, polished slickensided surfaces at 3,312.3 m MD. Core depths reported here are in meters measured depth along the main SAFOD borehole. Extent of low-velocity (after ZoBACK et al. 2010) and gas-rich zones (after WEIRSBURG and ERZINGER 2011) are shown for reference. Location of samples discussed in this paper are also illustrated

Southwest Deforming Zone (SDZ) at 3192 meters measured depth and the Central Deforming Zone (CDZ) at 3,302 $\mathrm{m}$ measured depth (after ZoBAcK et al. 2010), are surrounded by layers of cohesive black fault-related rock composed of cataclasite, ultracataclasite, sheared siltstone, and/or mudstone with block-in-matrix fabric (BRADBURY et al. 2011). As observed in the cuttings (BRADBURY et al. 2007), and supported by geophysical data (JEPPSON et al. 2010), additional faults and/or gouge zones may exist in the zone between $\sim 2.5$ and $4 \mathrm{~km}$, and borehole deformation occurred at the CDZ (JEPPSON et al. 2010).
To provide a broader geological context for our observations and analyses of SAFOD core (Fig. 2), we sampled numerous outcrops within the central to northern SAF system (Fig. 3) that included shear zones in serpentinite or serpentinite-derived clays (Allen 1968; Irwin and Barnes 1975; Moore and RYMER 2012). Large-scale strike-slip faults that cut serpentinite are common in regions where continental transform faults develop after plate convergence (Molnar and DAYem 2010). This allows us to conduct core to outcrop-scale analyses of the evolution, mechanics, and strength of serpentinite-bearing faults that have implications for other strike-slip fault 

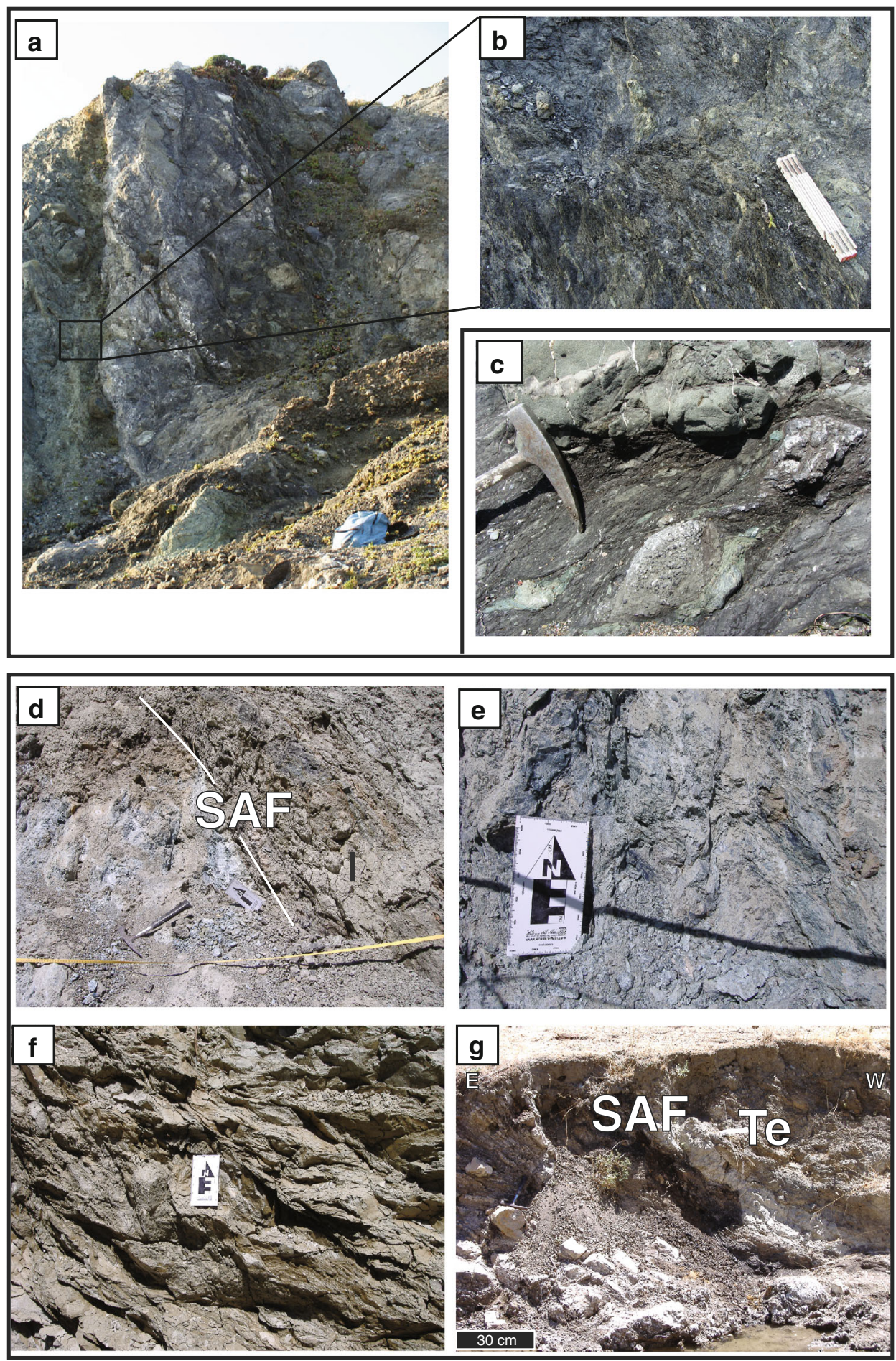
Figure 3

Images of surface outcrops sampled in this study: a view to north of SAF-related steeply east-dipping shear zone in shear zone of serpentinite-bearing Franciscan rocks exposed at Goat Rock State Beach, California (UTM WGS 84 10S, 489085 E, 4254741 N); b foliated phyllosilicate-rich gouge from shear zone at Goat Rock State Beach, California; c Block-in-matrix fabric exposed in sheared Franciscan mélange north of San Simeon State Beach, California (UTM WGS 84 10S, 0669047, 3941268 to 0668975 , 3941321); d Nelson Creek outcrop of the San Andreas Fault, approximately $2.3 \mathrm{~km}$ north of the SAFOD drill site (UTM location 10S, WGS 84, $720794 \mathrm{E}, 3986183 \mathrm{~N}$ ), where an approximately $6 \mathrm{~m}$ wide outcrop view of a strand of the San Andreas fault (SAF) juxtaposes sheared blue-green-grey serpentinite on the west (left) block against brown sheared mudstone and siltstone on the east (right) block. Fault dips approximately $60^{\circ}$ northeast; e sheared serpentinite at Nelson Creek approximately $50 \mathrm{~cm}$ from the primary slip surface with interlaced slickensided surfaces. Card is $16 \mathrm{~cm}$ long for scale; $\mathbf{f}$ sheared mudstone in the hanging wall or east block of the fault exposure at Nelson Creek, with numerous interweaving sheared surfaces. The phacoidal surfaces dip moderately to the west and exhibit a range of slip vector orientations. Approximately $50 \mathrm{~m} \mathrm{SE}$ of the Nelson Creek site, brecciated and highly fractured limestone lies within the fault on the NE block; and $\mathbf{g}$ another outcrop of a fault trace approximately $600 \mathrm{~m} \mathrm{SE}$ of the Nelson Creek exposure (UTM location 10S, WGS 84, 721282 E, $39858423 \mathrm{~N}$ ). Fault dips $53^{\circ}$ southwest. Carbonaceous material occurs within shear zone along the trace of the San Andreas fault (SAF). The Pliocene Etchigoin Formation sandstones (Te) lies in the west (right) block of the fault, and unnamed sandstone, siltstone, with clasts of serpentinite and sheared marble lie in the east (left) block. Neither unit is thought to be a petroleum source rock in the area, and thus the oil seep indicates the fault strand is

charged, and allows up-dip migration of liquid hydrocarbons

systems (BАRTH et al. 2013; Hirth and Guillot 2013; MOORE and LOCKNER 2013).

Previous and on-going analyses of whole-rock core suggests the mechanical properties of the SDZ and CDZ are likely influenced by: (1) the presence of neo-mineralized clay coatings on interconnected fracture surfaces (HoLDSwORTH et al. 2011; JANSSEN et al. 2012; SCHLeICHer et al. 2010, 2012); (2) formation of amorphous matter related to syndeformational fault lubrication (JANSSEN et al. 2010; RYBACKI et al. 2010); (3) cataclasis and brittle microfracture, intense shearing and multi-phased veins related to episodic deformation events and transient fluid flow (BRADBury et al. 2011; MOORE and RyMER 2012; RYBACKI et al. 2010); (4) pressure solution creep mechanisms (GRATIER et al. 2011; Holdsworth et al. 2011; MitTeMPHERGER et al. 2011); and (5) presence and/or transformation of frictionally weak minerals within clay gouge such as saponite, talc, and/or serpentine (CARPENTER et al. 2011; LOCKNER et al. 2011; MOORe and RyMer 2007; MoORe and RYMER 2012). In this paper, we also document the presence of carbon-rich materials and distinct geochemical alteration signatures adjacent to and within the fault zone. These data provide evidence for the role of fluids during deformation along the SAF near SAFOD.

\section{Composition and Texture of SAFOD Fault-Related rocks}

We describe the geologic and geochemical rock properties of fault-related rocks in the $\mathrm{SAF}$ at $\sim 3 \mathrm{~km}$ depth in the SAFOD borehole and for comparison, we present data from three near-SAF surface outcrop localities within serpentinite-bearing rock: San Simeon, Goat Rock Beach, and Nelson Creek, California (Figs. 1, 2, 3). We focus on the fine-scale to microscale variations in composition, alteration, and texture of additional samples from the three distinct fault-related rock type units identified adjacent to, or within, the actively deforming regions as described in a previous paper (Figs. 2, 3 and Table 2 of BRADBURY et al. 2011).

Detailed investigation of the fault-related rocks reveals distinct compositional and structural features that are similar to rock collected from the three outcrop localities and at several other serpentinitebearing or serpentinite-derived exposures throughout central to northern California (COLEMAN, 1996; Dibblee, 1971; Dickinson, 1966; Moore and Rymer 2012; PAGe et al. 1999; RyMER et al. 2003; SHERVAIS et al. 2004, 2011; Sims 1988, 1990). Observations and sampling of the surface outcrops provide additional insight into the composition and spatial variability of the internal structure of the fault and related damage zones at SAFOD and the potential physical and chemical processes that may occur at the meter to sub-meter scale in the active SAF.

The composition, alteration, and texture of Phase 3 whole-rock core samples were characterized by using petrographic thin-section studies, X-ray diffraction (XRD), X-ray fluorescence (XRF) analyses, scanning electron microscope (SEM) backscatter imaging, total organic carbon (TOC) measurements, determination of loss on ignition (LOI) values, and 


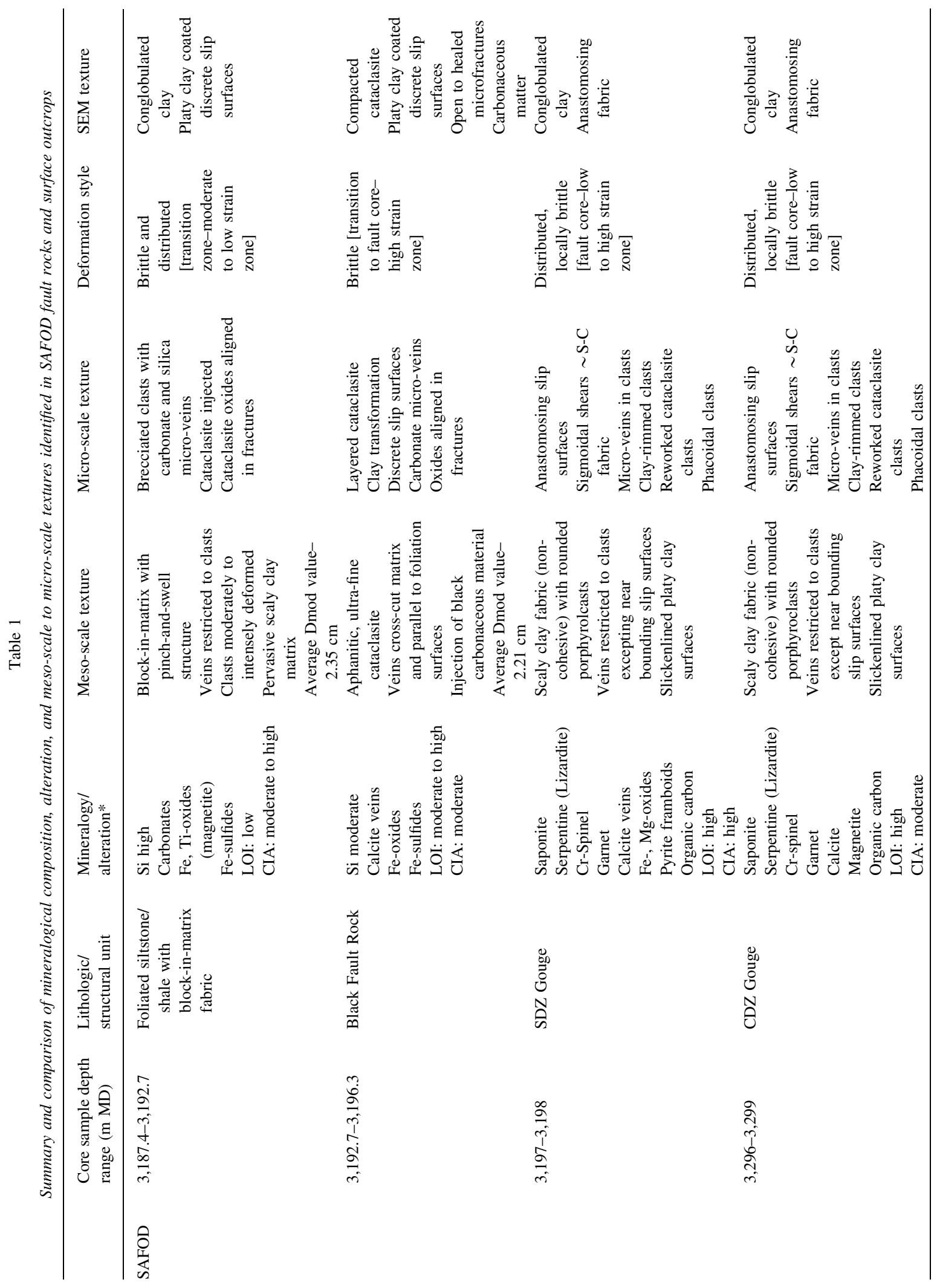


Evidence for Deformation Processes and Fluid-Rock Interactions

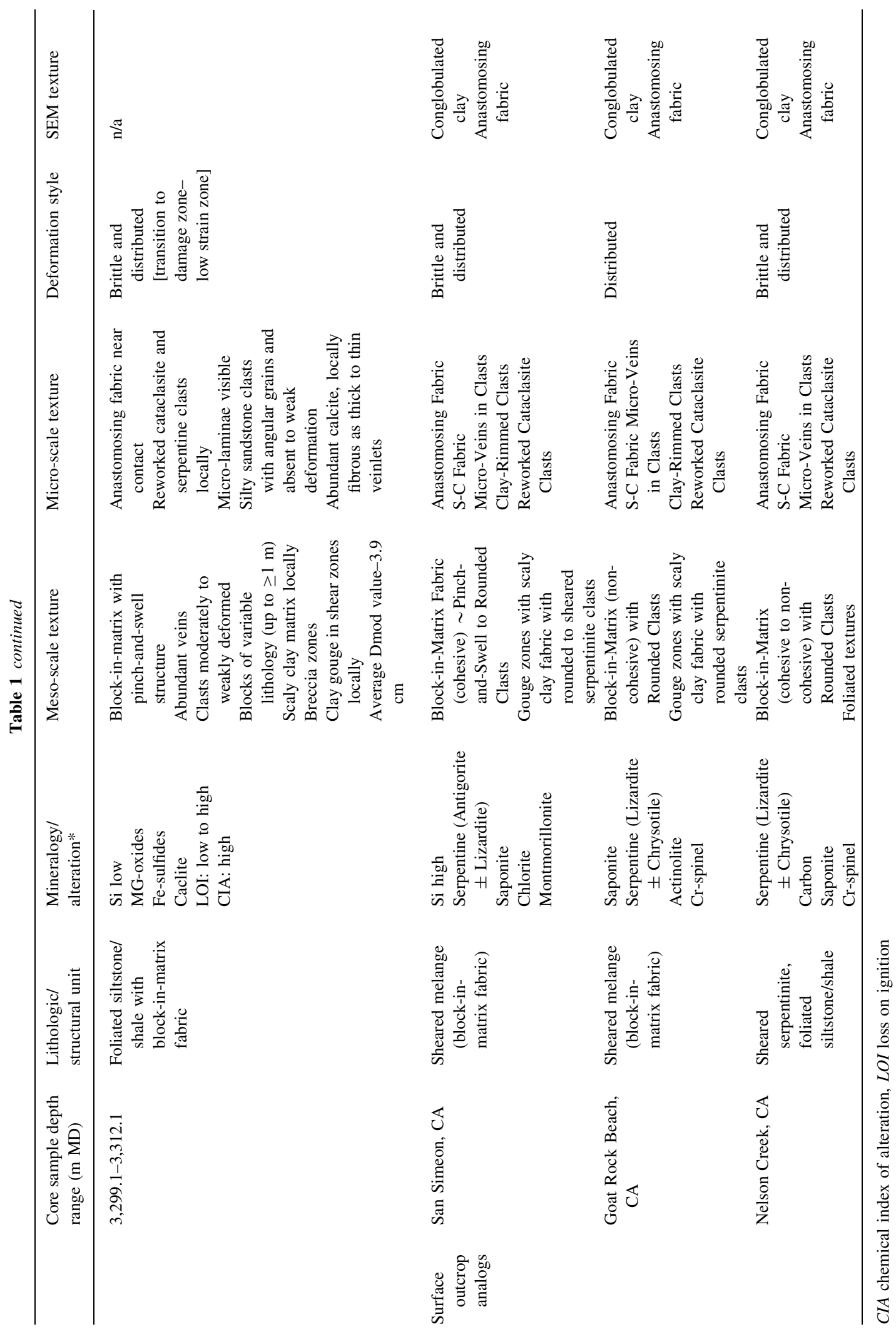


calculations of the Chemical Index of Alteration (Nesbitt and Young 1982; Table 1; Supplemental data files). Loose chips or slices of core $\sim 1 / 8-1 / 3$ of the core-diameter $(d=10 \mathrm{~cm})$ between 3,185 and 3,315 m MD were collected from the core; however, due to timing and/or restrictions related to the processing and distribution of the SAFOD Phase 3 whole-rock core, systematic sampling at regular, closely-spaced intervals has not been feasible. We report all depths for core samples as the measured drilling depth (m MD) along the deviated borehole.

We present results from the analyses of 25 total samples from the SAFOD near-fault environment, including: (1) foliated siltstone-shale with pinch-andswell block-in-matrix fabric (SILVER and BEUTNER 1980); (2) black cataclasite to ultracataclasite faultrelated rock; and (3) serpentinite-bearing and serpentinite-derived phyllosilicate-rich fault gouge (Table 1).

We also examine micro-scale composition, alteration patterns, and textures using petrographic thinsections, SEM, and XRD of $\sim 30$ surface samples collected at the three different surface outcrops, and compare these results to analyses of rocks sampled at SAFOD (Figs. 1, 2, 3, 4, 5, 6, 7; Table 1). We document the presence of three fault-related rock types in the core, and we suggest many of the samples collected at the three surface outcrops discussed in this paper are compositionally and texturally analogous to samples collected at depth at SAFOD, and thus, provide insight into scaling relationships of fault zone deformation and material properties and the 3D structural and permeability architecture of the SAF system surrounding SAFOD.

\section{Results}

\subsection{Foliated Siltstone-Shale with Block-in-Matrix Fabric}

Southwest of the SDZ, a foliated siltstone-shale unit with a scaly clay fabric and block-in-matrix texture (Fig. 2a, b) was sampled from $\sim 3,187.4$ to 3,192.7 $\mathrm{m}$ MD in SAFOD Phase 3 core (Table 1). This material contains intensely damaged clasts that commonly exhibit distorted to stretched and pinchand-swell shapes with numerous veinlets (Fig. 2a, h).
At the meso-scale, the average clast diameter is 2.35 cm (Table 1; method of MedLey and Goodman 1994) for the $10 \mathrm{~m}$ that it is cored southwest of the SDZ. The matrix surrounding the clasts is pervasively fractured, with local variations in the degree of shearing. Intensely fractured zones are characterized by highly polished black slip surfaces (Fig. 2i) or zones of irregular black staining (Fig. 2b). This unit of moderate to intensely damaged rock also correlates to a broad $(>200 \mathrm{~m}$ ) region of low velocity waves measured at SAFOD (ELLSWORTH et al. 2011; JEPPSON et al. 2010; ZоBACK et al. 2010).

Northeast of the CDZ contact, a 3-m wide zone of similar damaged rock occurs and consists of sheared siltstone/mudstone with block-in-matrix fabric and pinch-and-swell structures, and is pervasively fractured and dissected by cm-wide shear zones and abundant $\mathrm{mm}$ - to cm-thick calcite veins (Fig. 2h, i). Here, several veins exhibit fibrous calcite growth (Fig. 2h). In general, damage intensity decreases to the northeast of this contact, as indicated by clast or block size, relative fracture intensity, and the number of veinlets within clasts (see Phase 3 Core Photo Atlas, http://www.earthscope.org; BRADBURY et al. 2011); however, localized zones of intense fracturing and shear are observed to the end of Phase 3 core at $\sim 3,312.7 \mathrm{~m} \mathrm{MD} \mathrm{(Fig.} \mathrm{2).} \mathrm{The} \mathrm{meso-scale} \mathrm{average}$ clast diameter for block-in-matrix units increases to $\sim 4 \mathrm{~cm}$ (Table 1) within the first $10 \mathrm{~m}$ to the northeast of the CDZ slip surface, with a few 1-2 m blocks of siltstone and sandstone that exhibit only minor damage and a significant decrease in overall fracture intensity.

At the microscale, the block-in-matrix rock unit is characterized by sedimentary lithic fragments, reworked cataclasite (Fig. 4a), and/or clay-clast aggregates (see BoutAREAUD et al. 2008, 2010) embedded within fine-grained, sheared cataclasite bands with internal layering alternating with foliated scaly clay-rich rocks, fine-grained cataclasite, and/or breccia. Within the cataclasite bands, thin seams of irregular and discontinuous opaque oxides, primarily magnetite, infill fractures parallel to the foliation (Fig. 4a). Injection-like structures filled with distinct black-ultrafine matrix, cataclasite, and clay are oriented at sharp boundaries perpendicular or oblique to the main cataclasite fabric (Fig. 4a). Multiple 


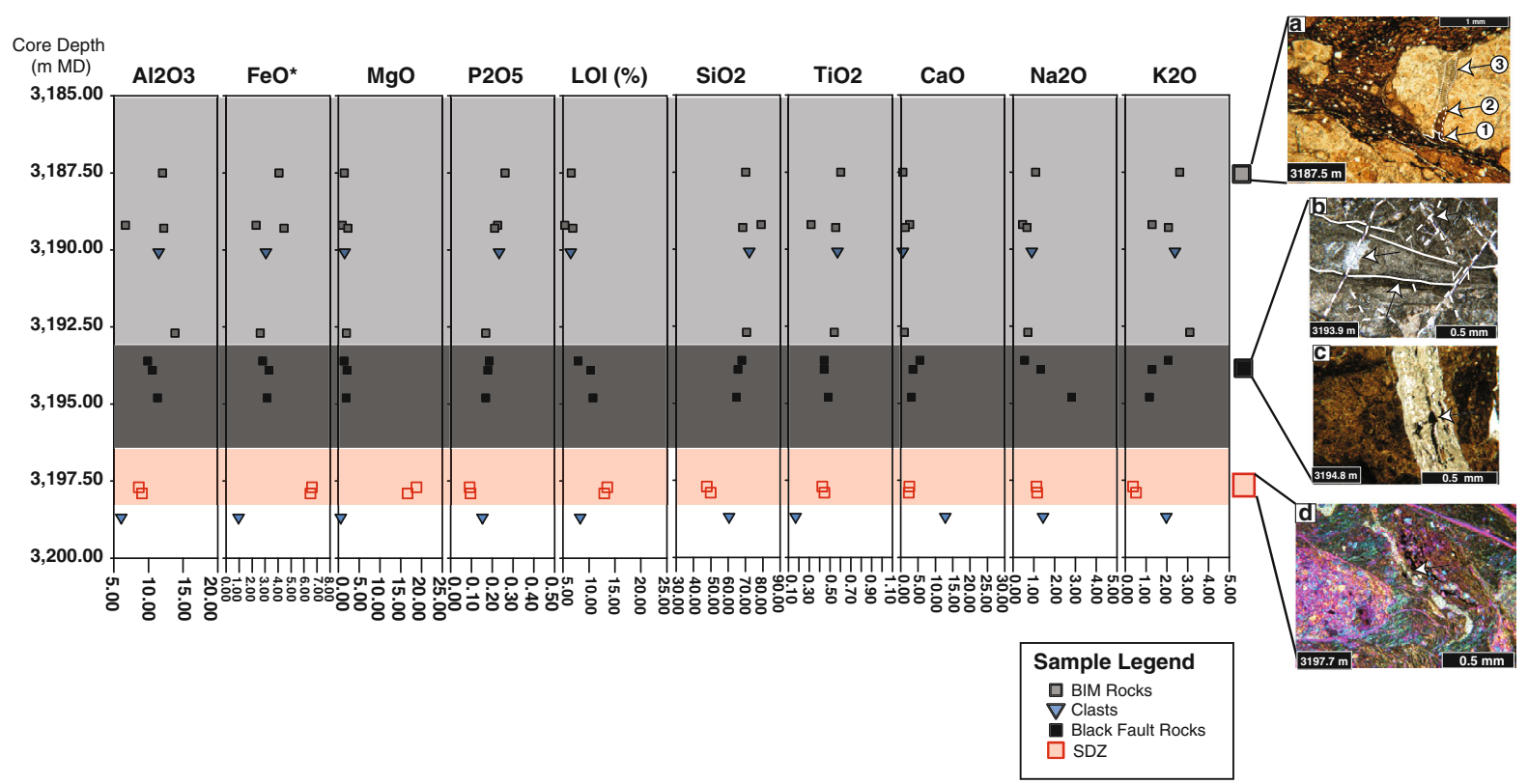

Figure 4

XRF-ICPMS Data and Photomicrographs of textures of deformed rocks within Phase 3 SAFOD core Hole G, Runs 1-3, which intersected the SDZ (highlighted in $r e d$ ): a Brecciated claystone and cataclasite with flow-like and injection-like morphologies (view is plane polarized light); fractures are filled with opaque groundmass that form boundaries parallel to cataclasite foliation direction and connect to multiple high-angle to perpendicular zones of injected catacalsite at $3187.5 \mathrm{~m} \mathrm{MD}$. Brecciated textures and surrounding carbonate mineralization indicate repeated opening, sealing, and deformation. Multiple generations of cataclasite and reworked ultracataclasite are also observed to extend into the injection-like fractures (as shown by white arrows and labeled 1 to 3 from youngest to oldest, respectively) and associated with distinct alteration where the lighter gray clay and carbonates are inferred to be older as they are injected by the darker, younger cataclasite/ ultracataclasite; b Multiple episodes of slip produce alternating fine to ultrafine layers of cataclasite and ultracataclasite of the black faultrelated rock at 3,193.9 m MD suggest repeated slip has created localized slip surfaces. Multiple generations of dilational, fine carbonate and quartz veins offset the groundmass, older veins at high-angles, and shear planes. Spherules of pyrite are present within the darker bands of ultracatalasite near the center of the photograph; $\mathbf{c}$ Magnified view of the vein morphology in polarized light, providing evidence for multiple fluid phases of varying fluid chemistry at $3,194.8 \mathrm{~m}$ where black opaque mineral in the center of calcite-filled fracture is pyrite, suggesting a late phase reducing fluid pulse; $\mathbf{d}$ rounded clasts of sedimentary lithics and serpentinite entrained within SDZ fault-gouge at 3,197.7 m (view is polarized light with gypsum plate inserted). Flow-like textures surround clasts, and numerous clasts exhibit altered rinds or attached gouge material and/or fractures, and many veins exhibit distorted morphologies (dashed line). Features that may be indicative of slow, recurrent aseismic slip with fluctuations in fluid interactions. Major element whole-rock geochemistry (XRF/ICPMS) analyses conducted at Weber State University SEM Lab

generations of cataclasite and brecciation are observed with varying degrees of alteration (Fig. 4a). High-resolution SEM images show shear zones are at high-angles to the foliation fabric of the matrix and contain well-developed platy clay infilling (Fig. 8a, b). The clast aggregates consist of conglobulated (rounded) clay and/or reworked cataclasite grains that appear to have rotated and flowed between bounding fracture/foliation surfaces, and may contain continuous to discontinuous rims of surrounding reworked and/or altered gouge matrix (Fig. 8d). Quartz, feldspar, smectitic clays, and magnetite are the primary mineralogical constituents of this rock unit, with relative increases in Fe-rich sulfides and $\mathrm{Mg}$-oxides disseminated throughout the matrix and locally seen as fracture infillings (Table 1; also refer to BRADLEY et al. 2011).

The XRD results indicate Mg-rich palygorskite occurs locally within the fine-grained matrix of SAFOD samples (Table 1; refer to BradBury et al. 2011). Results for 12 samples with XRF-ICPMS analyses show Si concentrations are high southwest of the SDZ, low within the SDZ and CDZ, moderate to high adjacent to the $\mathrm{CDZ}$ boundary, and decrease to moderate values east of the CDZ (Figs. 4, 5). Southwest of the SDZ boundary, the block-in-matrix 


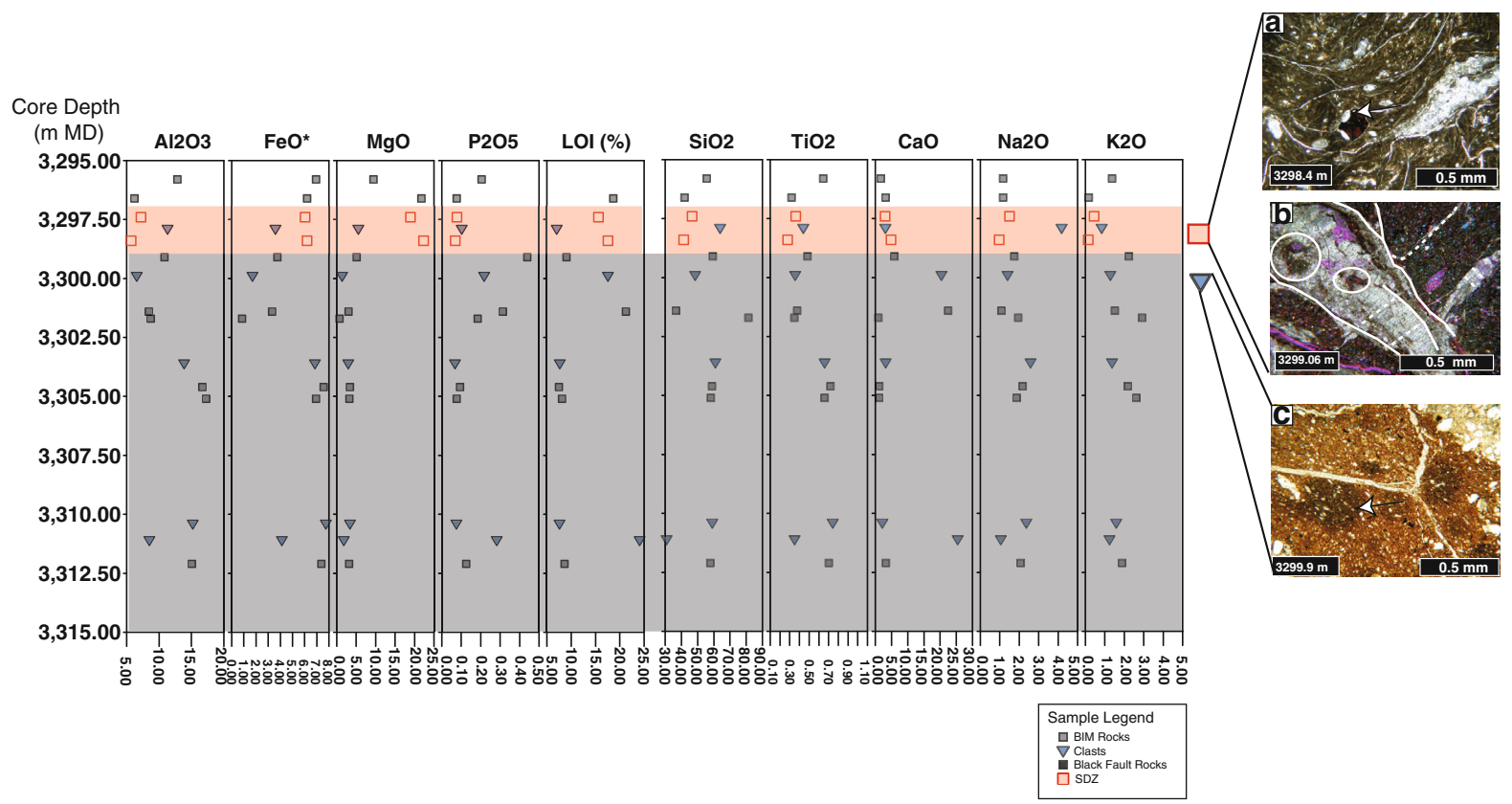

Figure 5

XRF-ICPMS Data for Phase 3 SAFOD core Hole G, Runs 4-6, which intersected the CDZ (highlighted in red): a CDZ fault gouge at 3288.4 $\mathrm{m}$ MD exhibits scaly fabric at the microscale. Note the deep red Cr-spinel grain in the lower left corner of the photo has silica mineralization attached to the fractured surfaces and infilling the microveinlets; b CDZ fault gouge at 3,299.08 m MD includes a multi-layered carbonate vein that runs parallel to foliation and connects to multiple high-angle veins oriented perpendicular to fracture (see MiTTEMPERGHER et al. 2011 for comparison). Pieces of surrounding matrix occur within veinlet (white circles), and also suggest repeated dilation, healing, and deformation within the CDZ; and c A clast (Core G-4-6) within the block-in-matrix structural unit (BIM rock) adjacent to the CDZ at 3299.9 $\mathrm{m}$ MD contains darker spherical stains of organic carbon that contribute to the relatively high TOC values (Table 2) adjacent to and within the

fault zone. Major element whole-rock geochemistry from XRF/ICPMS analyses conducted at Weber State University SEM Lab

rocks are high in silica and locally high in calcite (likely associated with intraclast veining), with titanium oxide and iron oxide also present in moderate amounts (Table 1; Fig. 4). Total organic carbon (TOC) measurements southwest of the SDZ, between 3,187.4 and 3,189.3 $\mathrm{m} \mathrm{MD}$, averages $\sim 1.2$ $\%$ (Table 2), with higher values associated with black irregular staining (Fig. 2). Northeast of the CDZ, between 3,299 and 3,301.5 m MD, average TOC increases to $\sim 1.4 \%$ and hydrocarbons are observed locally at the micro-scale (Fig. 5c). Values of volatile elements measured by loss on ignition (LOI) are low relative to rocks to the immediate east and to the SDZ fault gouge (Table 1; Fig. 4).

We apply the Chemical Index of Alteration (NesbitT and Young 1982) to test for any observable patterns in geochemical alteration of SAFOD samples, particularly across the active fault zone, where the ratios of major elemental oxides from XRF analyses are used in the following equation:

$$
\begin{aligned}
& \text { Chemical index of alteration } \\
& \begin{array}{l}
=\mathrm{CIA}=\mathrm{Al}_{2} \mathrm{O}_{3} /\left(\mathrm{Al}_{2} \mathrm{O}_{3}+\mathrm{Na}_{2} \mathrm{O}\right. \\
\left.\quad+\mathrm{K}_{2} \mathrm{O}+\mathrm{CaO}\right) \times 100
\end{array}
\end{aligned}
$$

Typically, CIA values for clay are in the range of $75-100$, with muscovite $\sim 75$, feldspars $\sim 50$, and fresh igneous rocks $\sim 30-55$ (NesBitT and Young 1982). However, the presence of carbonates (e.g. veinlets, cement) may lead to low and unreliable CIA values (BAHLBERg and Dobrzinski 2011). The CIA values are typically moderate to high for the phyllosilicate-rich material in the block-in-matrix units and in the SDZ and CDZ (Tables 1,2) due to the abundance of clays within the gouge matrix. In general, samples that include fragments, or that are entirely composed of clasts with carbonate veinlets show highly variable compositions (Table 2) and lower CIA Index values (Table 2). Locally, the presence of calcite veins may increase the LOI for clasts relative to the surrounding phyllosilicate 
Table 2

Percent Total Organic Carbon (TOC) and application of the Chemical Index of Alteration (CIA after NESBITT and YouNG 1982) determined from whole-rock geochemical analyses on SAFOD Phase 3 core fault-related rocks

\begin{tabular}{|c|c|c|c|}
\hline Sample depth (m) & Structural unit & TOC & CIA $(\%)$ \\
\hline $3,187.4$ & Foliated siltstone/shale with block in matrix fabric & 1.5 & 73.5 \\
\hline $3,189.3$ & Foliated siltstone/shale with block in matrix fabric & 0.9 & 75.0 \\
\hline 3,193 & Foliated siltstone/shale with block in matrix fabric & 0.5 & na \\
\hline $3,193.6$ & Black Fault Rock & 1.1 & 55.0 \\
\hline $3,193.9$ & Black Fault Rock & 0.4 & 63.2 \\
\hline $3,298.4$ & CDZ Fault Gouge & 0.4 & 48.9 \\
\hline 3,299.1 & Contact with $\mathrm{CDZ} /$ Foliated siltstone/shale with block in matrix fabric & 1.6 & 52.4 \\
\hline 3,299.9 & Foliated siltstone/shale with block in matrix fabric & 1.9 & 22.1 \\
\hline $3,301.4$ & Foliated siltstone/shale with block in matrix fabric & 1.5 & 25.1 \\
\hline $3,303.6$ & Foliated siltstone/shale with block in matrix fabric & 0.8 & 65.9 \\
\hline $3,310.4$ & Foliated siltstone/shale with block in matrix fabric & 0.9 & 71.4 \\
\hline $3,312.1$ & Foliated siltstone/shale with block in matrix fabric & 0.7 & 67.4 \\
\hline
\end{tabular}

Sample preparation conducted at USU with XRF-ICPMS analyses run at Washington State University (WSU). Total organic carbon was measured at the University of New Mexico Analytical Geochemical Laboratory

matrix, in addition to several gouge samples analyzed from the SDZ and CDZ (Fig. 4).

\subsection{Black Ultrafine-Grained Cataclasite 3,192.7-3,193.6 m MD}

Near the southwestern edge of the SDZ, ultrafine, cohesive black fault-related rocks are present from 3,192.7-3,196.3 m MD (Figs. 2c, 5c). At the mesoscale, this distinctive black rock appears massive to locally finely layered, with $\mathrm{mm}$ - to $\mathrm{cm}$-thick layers of brown to gray-black cataclasite and is characterized in thin-section by alternating fine laminations of cataclasite, variably altered clay, and hydrofracture veins, with slight changes in grain size between layers of cataclasite (Figs. 2b, 5c). The meso-scale average clast diameter of $2.2 \mathrm{~cm}$ within the black fault-related rock unit is the smallest for all units measured (Table 1). Discrete slip surfaces offset the multi-layered zones of fine to ultrafine-grained cataclasite (Fig. 5). Veins filled with calcite and locally pyrites are parallel to or at high-angles to the foliation direction within the fine-grained groundmass (Fig. 5c). Several veins (mm-thick to $\mathrm{cm}$-thick) contain a visible central fracture interface filled with carbonates, Fe-sulfides and Mg-oxides (Fig. 4c), suggesting that cyclic pulses of fluids with differing redox states occurred in the fault zone. Pyrite framboids are also present as isolated masses within the gouge matrix (Fig. 8c). Numerous thin $(\leq 1 \mathrm{~mm}-$ thick) carbonate veins are both parallel and at high angles to the ultrafine comminuted material, and may crosscut older vein systems (Fig. 5). An increase in the abundance of magnetite is observed at the microscale in both the groundmass and concentrated within fracture fillings (BRADBURY et al. 2011). Silicaconcentrations are moderate within the few samples tested; this reflects local increases in $\mathrm{Na}-$, Ti-, Al-, and Fe-oxides (Fig. 4). The TOC values show an overall decreasing trend towards the SDZ boundary with values ranging from $\sim 0.4$ to $1.1 \%$; however, because black carbon-rich zones or staining parallel to a fractures were observed in numerous places throughout the core, more systematic sampling is necessary to better define the nature and distribution of carbon-rich material. Calculated CIA values are moderate for this unit and are slightly lower than the block-in-matrix unit, and higher in comparison to samples from the CDZ (Tables 1, 2). Values for LOI $\%$ are moderate and appear to increase towards the SDZ (Fig. 4).

\subsection{Southwest Deforming Zone (SDZ) and Central Deforming Zone (CDZ)}

The SDZ is sampled in the core from $\sim 3,197$ to 3,198 m MD core depth, and the CDZ from 3,296 to $\sim 3,299 \mathrm{~m} \mathrm{MD}$ core depth, corresponding to the low-velocity zone (Fig. 2d, e) reported by ZовACK et al. (2010) in the borehole geophysical logs at 
$\sim 3,192$ and $\sim 3,302 \mathrm{~m} \mathrm{MD}$, respectively. The rocks of the SDZ and CDZ exhibit a non-cohesive scaly clay fabric (VANNUCCH et al. 2003) enveloping rounded to elongate clasts of predominately serpentinite, clay, quartz, reworked cataclasite, or finegrained altered sedimentary or volcanic lithic clasts of mixed composition (Figs. 2d, g, 4, 5, and 6c, e).

The complex array of anastomosing surfaces within the scaly clay fabric displays textural selfsimilarity on all scales. Loose fragments of fault gouge from the core show pervasive polished and striated surfaces (Fig. 3; Schleicher et al. 2006; 2010). Petrographic observations (Figs. $4 d, 5 a, b$ and $6 \mathrm{c}$, e) reveal anastomosing phyllosilicate-rich seams surround interlayers of fine-grained cataclasite, rotated or sheared clasts and reworked cataclasite fragments, and/or carbonaceous material.

The XRD analyses show the fault gouge matrix is predominately composed of saponite with lizardite \pm chrysotile and magnetite (BRADBURY et al. 2011; LOCKNER et al. 2011; MoORE and RyMer 2012). Many clasts within the matrix are mantled by an outer rim of clay or contain altered material surrounding the edges (Figs. 4d, 5a, b and 8e, f). Localized zones of cataclasite and microbreccia that are in turn, surrounded by more competent elongated and rotated clasts mantled with clay or reworked cataclasite with apparent flow features (Figs. 4d, 5a, b).

Calcite veins are generally restricted to the isolated clasts or blocks of serpentinite, with the exception of the main shear zones. If present within fault gouge, they are commonly parallel or perpendicular to the foliation direction (Fig. 2c, d, h). At the micro-scale, the calcite veins may appear curvilinear or slightly disrupted and fragmented by reworking (Figs. 4d, 8d). Pyrite occurs as isolated framboids and spherules in the fine-grained gouge matrix and as euhedral crystals adjacent to and lining numerous fracture surfaces (Fig. 8c-f). Distinct high-pressure and/or temperature minerals in the matrix and/or clasts include Cr-rich spinel, Ti-sphene, and andradite garnet (Table 1; Fig. 6c).

We apply the CIA calculation to the whole-rock geochemical data as a proxy for alteration and/or hydration within the SDZ and CDZ relative to the surrounding rock samples (Table 2; Figs. 4, 5). Individual clasts within the fault gouge show low CIA values typically associated with unaltered protolith and/or mafic rock compositions (NESBITT and YounG 1982). The XRF analyses of samples in both the SDZ and $\mathrm{CDZ}$ show fault gouge has higher $\mathrm{FeO}$ and $\mathrm{MgO}$ concentrations than samples in the surrounding rocks (Figs. 4, 5). The Ni-, Ti-, and $\mathrm{Cr}$-oxide values are also relatively high within clasts entrained in the fault gouge and locally as individual grains within the matrix. Cr-spinel and andradite garnet were identified in several thin-sections (MoORE and RyMer 2009, 2012) and in additional samples by SEM and XRD analyses (BRAdBury et al. 2011; Figs. 4, 5, 8, 9; Tables 1 and 2). In the CDZ, one sample measurement shows a TOC value of 0.4 (Table 2); however, due to the highly localized nature of black carbonaceous material along fractures, additional testing is required to delineate any sort of pattern. The LOI values are higher in the SDZ and CDZ relative to surrounding rocks with the highest values present within the CDZ fault gouge material (Figs. 4, 5) and support the presence of either organic carbon/hydrocarbons (BALL 1964) or significant hydration and alteration of the host-rock (Schulz and Evans 2000).

\subsection{Surface Outcrop Analogs}

We examined numerous surface outcrops along the San Andreas Fault system and within exposed and sheared lenses of faulted serpentinite-bearing matrix mélanges and/or sheared mixed serpentinites and sedimentary rocks (Figs. 3, 6, 7, 9) from central to northern California (Fig. 1) to further evaluate the nature of faulted serpentinites and to provide context for the shear zones sampled in Phase 3 core. The three outcrop site localities we discuss here include: (1) near the San Simeon Beach where the San GregorioHosgri fault system cuts the serpentinite-bearing Franciscan Formation (BAILEY et al. 1964; CowAN 1978; Hsü 1969; Singleton and Cloos 2012); (2) Goat Rock Beach, where a shear zone within the Franciscan mélange is exposed east of an offshore active strand of the San Andreas fault (BLAKE et al. 2002); and (3) Nelson Creek, about $2 \mathrm{~km}$ north of the SAFOD intersection with the SAF in a serpentinite-bearing shear zone with adjacent foliated siltstones and mudstones of the Great Valley Formation (Moore and RYMER 2012) and in another exposure of faulted 

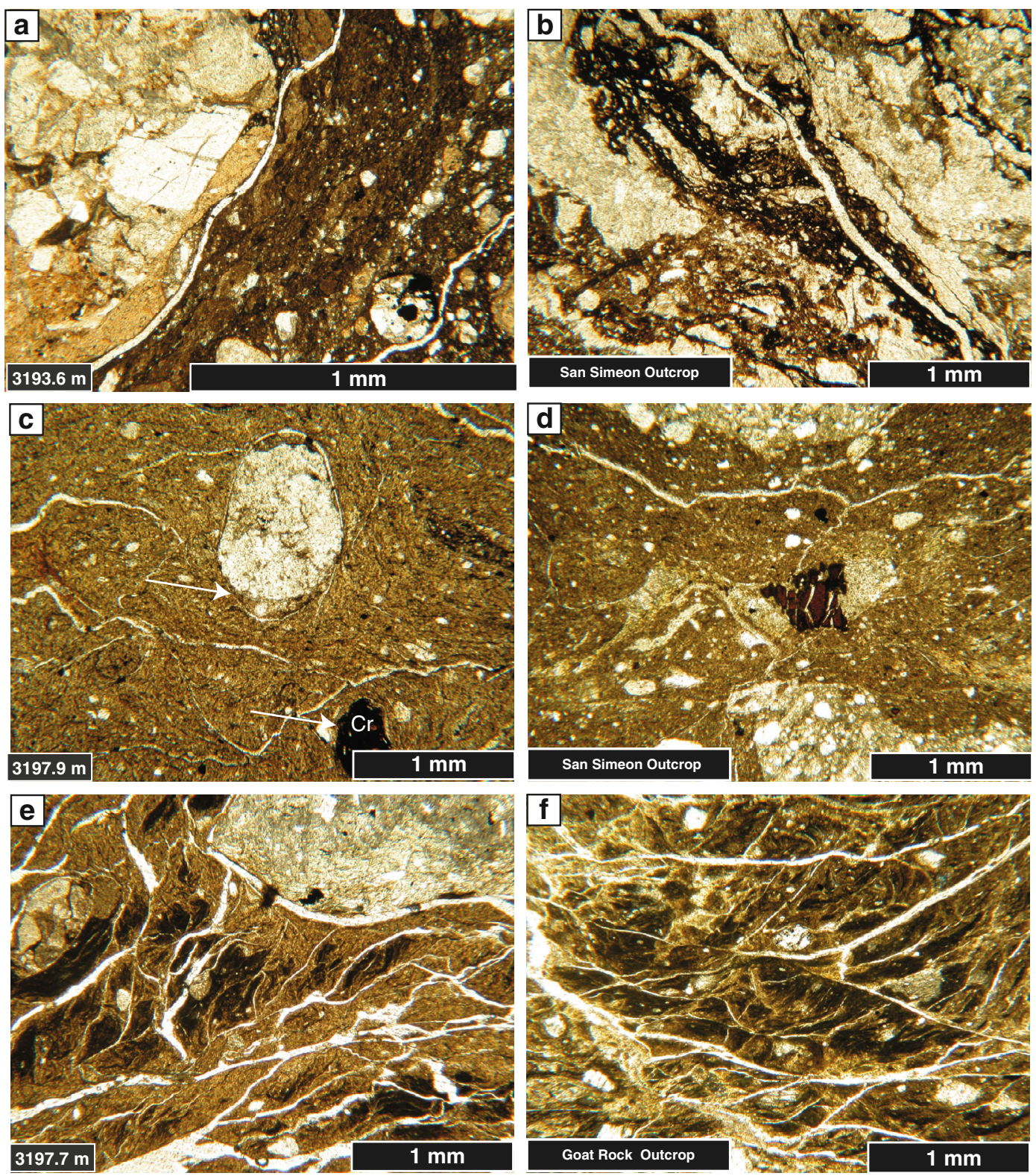

Figure 6

Thin-section photographs of sheared rocks in SAFOD Phase 3 samples shown in the left column versus analog materials shown on the right and sampled from exhumed exposures of Franciscan mélange, central to northern California. Strong similarities exist and suggest SAFOD fault-related rocks have experienced similar processes during deformation and fluid-rock interactions, and/or the SAFOD rocks sampled in the shear zones contain Franciscan protolith. a Black fault-related rock adjacent to the SDZ from SAFOD Phase 3 Core at 3,193.6 m MD; b Black fine-grained rock within exposure of Franciscan mélange sampled near San Simeon, CA; c Fault gouge associated with SDZ from SAFOD Phase 3 Core 3,197.9 m MD; note alteration rind surrounds clast and contains coating of surrounding groundmass suggesting rotation of clast; note opaque to dark-red, high-relief grain near base of picture (Cr-Spinel (Cr); Also refer to Figs. 3-7 of MooRE and RYMER 2012); d Sheared fault gouge from near San Simeon that contains clasts of recycled cataclasite and distinct grains of dark red Cr-spinel, similar in both composition and texture to the SAFOD fault gouge of $\mathbf{c}$; e Samples fault gouge at the micro-scale illustrate the distinct pervasively foliated texture associated with the SDZ and CDZ of SAFOD (shown is the SDZ at 3,197.7 m MD); carbon analyses suggest that the isolated and darker colored groundmass may be infused with hydrocarbons); and f Sheared phyllosilicate-rich rocks within the Franciscan Formation near Goat Rock, northern CA are nearly identical to the textures shown in (e) 

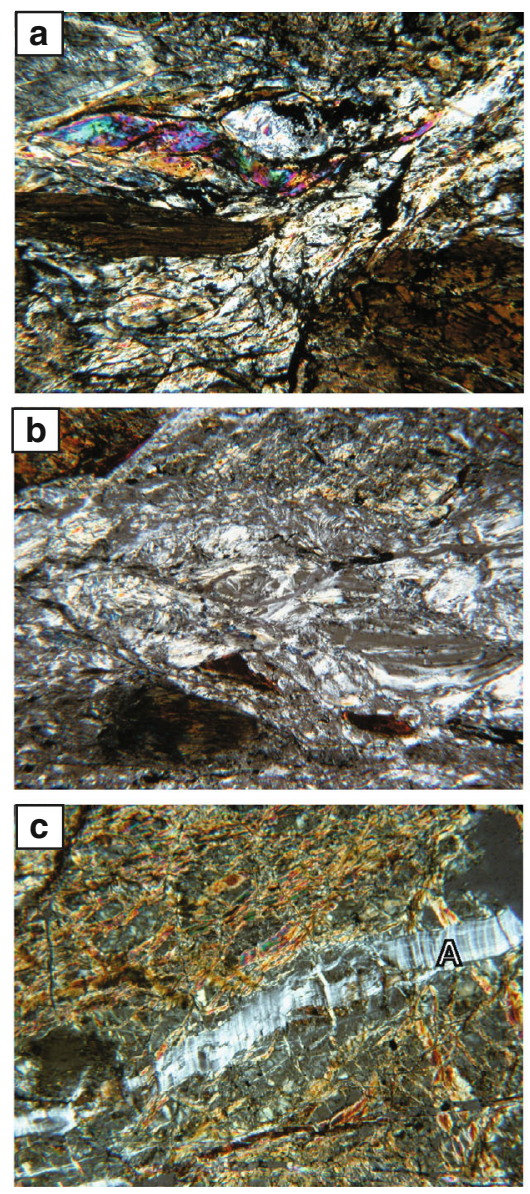
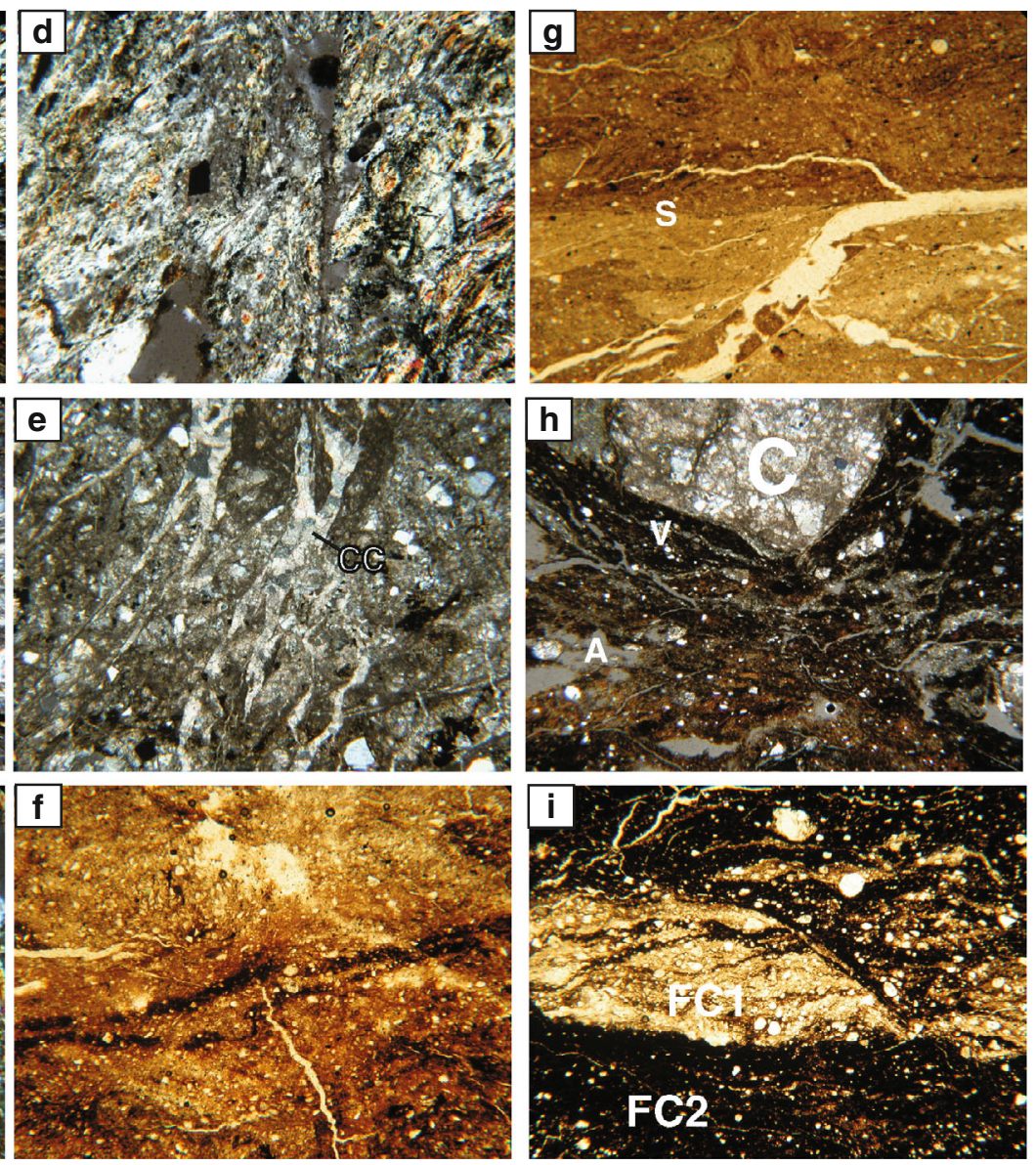

\section{$4 \mathrm{~mm}$}

Figure 7

Optical photomicrographs of samples from the Nelson Creek outcrop. All samples are from the transect shown in Fig. 3d. Images a-e are cross-polarized light images, and f-i are plane polarized light images: a sheared serpentinite with original brown hornblende and biotite and white-grey sheared alteration products of lizardite and chrysotile; b foliated serpentinite cut by thin horizontal shear surfaces; $\mathbf{c}$ altered serpentinite cut by fibrous antigorite-chrysotile vein (A); d foliated serpentinite with pyrite grains (black grains); e evidence for pore-fluid pressure lies in the presence of calcite veins, V, that cut the cataclasite; $\mathbf{f}$ clay-rich sample from the sheared serpentinite west of the fault contact at the Nelson Creek 1 outcrop, with dark hydrocarbon-rich staining; $\mathbf{g}$ fine-grained clay-rich sheared rock of the slip surface (S) from Nelson Creek 1 site; $\mathbf{h}$ clast of fine-scale cataclasite (C) cut by foliated hydrocarbon-rich cataclasite, cut by thin veins (V) from the Nelson Creek 2 site; and $\mathbf{i}$ repeated slip and development of foliated cataclasite in the hydrocarbon-rich fault dominated rocks in the fault strand fault is shown by light clast of foliated cataclasite, with horizontal banding (FC1) as a clast within dark second phase of foliated cataclasite (FC)

from the Nelson Creek site shown in Fig. $3 \mathrm{f}$

sedimentary rocks dissected by a hydrocarbon-bearing fault zone (Figs. 1, 3). Comparison of the faultrelated rocks from SAFOD to the samples collected at the surface outcrops indicate that the rocks are compositionally and texturally analogous. For example, near San Simeon, CA (Fig. 3), black ultrafine rocks exhibit laminated to contorted morphologies in narrow (cm-wide to m-wide) shear zones surrounded by a serpentinite-bearing block-in-matrix mélange. From the meso-scale to micro-scale, the exhumed black rocks are similar in composition and texture to the black fault-related rock unit sampled in SAFOD Phase 3 Core (Figs. 2c, 5c, 6; Table 1), whereas the surrounding foliated serpentinite-bearing scaly clay matrix compares to the fault gouge of the SDZ and CDZ (Figs. 2d-g, 3, 6). 
Fault-related rocks from the SDZ (Figs. 2d, e, 4d) and CDZ (Figs. 2f, g, 5a, b) exhibit evidence for brittle and ductile deformation at the micro-scale. Evidence for brittle deformation includes the presence of broken grains, reworked cataclasite fragments, and discrete microfractures (Figs. 4d, 5a, b, 6, 8). Flow-like morphologies of the faulted rocks, block-in-matrix fabrics, and S-C fabrics in the fault gouge all support an interpretation of distributed shearing within these zones (Fig. 6d, e). Samples from the CDZ (Fig. 6e) and Goat Rock Beach (Fig. 6f) both contain complex anastomosing networks of slip surfaces. This distinct fabric is also identified in SEM images of thin-sections for samples from the SDZ and Goat Rock Beach (Fig. 9a-c).

Sheared mélange samples from San Simeon and Goat Rock (Fig. 3a-c) occur in tabular zones that are on the order of several meters thick and exhibit deformation features uniquely similar to those observed in the SDZ and CDZ rock samples from SAFOD Phase 3 core (BRADBURY et al. 2011; Gratier et al. 2011; HoldSwORTh et al. 2011). At the San Simeon site, the rocks appear more cohesive relative to the non-cohesive gouge sampled in the SAFOD core; however, at finer scales, the structures are analogous (compare Figs. 6, 8, 9). The sheared melange matrix from near San Simeon also contain numerous clasts of recycled cataclasite (Fig. 5e), calcite veins, pyrite framboids and spherules, and distinct grains of dark red Cr-spinel, with similar mineralogies to those observed in both the SDZ and CDZ fault gouges (Figs. 6, 8, 9).

The San Andreas Fault is exposed at the Nelson Creek surface outcrop, $\sim 2.3 \mathrm{~km}$ northeast of the SAFOD site (Figs. 1, 3, 7). MoOre and Rymer (2012) described this outcrop, show these rocks are texturally and mineralogically similar to those observed in the SAFOD core, and suggest they are linked to the SDZ and CDZ at depth. The Nelson Creek outcrop consists of large blocks of serpentinite entrained within a non-cohesive, Mg-rich scaly clay gouge (Fig. 3d-g; Moore and Rymer 2012). At the outcrop scale, the fault consists of sheared serpentinite west of the fault contact next to clay-rich sheared rocks to the east. Serpentinite here has a blue-grey cast (Fig. 3d, e), and numerous surfaces have striations with a range of orientations. The cm-scale interweaving of slip surfaces is common with the 3 $\mathrm{m}$ east of the fault (Fig. 3f), and multiple orientations of slip vectors are recorded on slip surfaces, where narrow zones of indurated cataclasite are faulted next to clay-coated fault surfaces. The delicate nature of the clay-coated surfaces may have formed in the 2004 Parkfield earthquake (Moore and RyMer 2012), and the multiple slip vectors suggest that surface ruptures have complex slip geometries. To the south, the fault cuts sedimentary rocks where multiple generations of cataclastically deformed clasts lie in a clayey-hydrocarbon rich matrix (Fig. 3g). At the micro-scale (Fig. 7), the serpentinite-rich unit is foliated and sheared and cut by veins of lizardite and fibrous chrysotile, calcite, with localized pyrite mineralization (Fig. 7a-e). Fine-grained sedimentary rocks contain multiple-layers of cataclasite and clay gouge with irregular dark hydrocarbon-rich staining that are cut by thin veinlets of calcite (Fig. $7 \mathrm{f}-\mathrm{h}$ ).

\section{Discussion}

The mineralogical, textural, geochemical, and geophysical signatures described here and by others (Bradbury et al. 2011; CARPENTER et al. 2011; LOCKNER et al., 2011; ZовACK et al. 2010), characterize the SDZ and CDZ fault strands separated by over $100 \mathrm{~m}$ in the SAFOD borehole. These fault strands are possibly linked at depth (BRADBURY et al. 2009) and extend to the surface (the Nelson Creek outcrop of MoORE and RyMer 2012 also described here), to form a wide zone of deformation characterized by an anastomosing network of foliated, phyllosilicate-rich fault rocks within which narrow slip surfaces are locally separated by blocks or lenses of competent and/or less deformed rocks (including sedimentary and volcanic rocks) in the shallow crust (BRADBURY et al. 2009). The comparisons presented here between the composition and texture of the SAFOD fault rocks and the San Simeon and Goat Rock outcrops within the Franciscan Formation, and the work by Moore and Rymer (2012) on the Nelson Creek outcrops of the Coast Range Ophiolite, suggest the processes operating within the SAF during deformation may be comparable to those that affected these near-surface outcrops. Thus, these structures, 

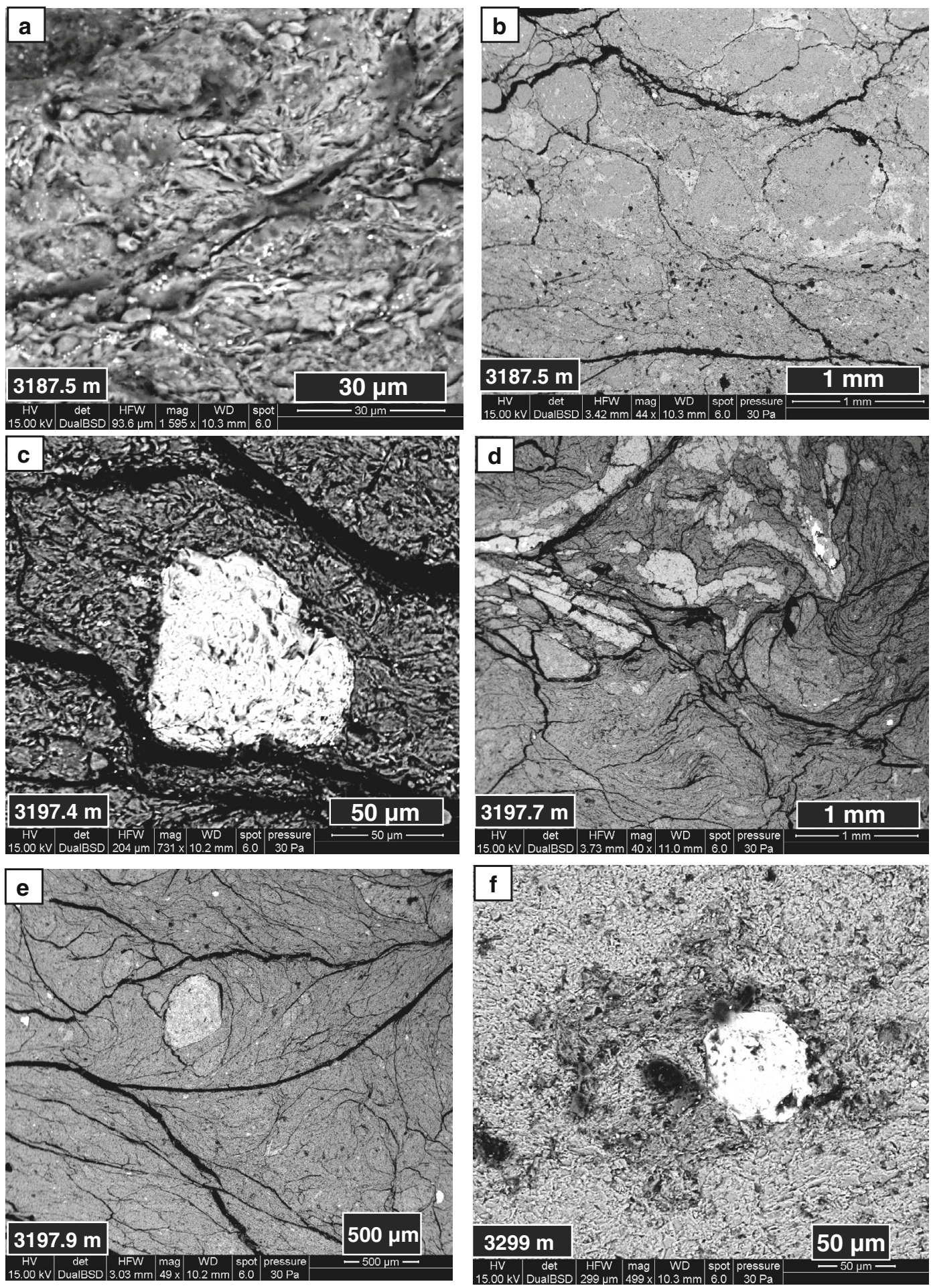
Figure 8

Scanning Electron Microscope images of SAFOD Phase 3 Core: a neomineralized clay growth (e.g. SCHLEICHLER et al. 2010) within hairline fractures of black fault-related rock at 3,187.5 m MD); b conglobulated textures between localized slip surfaces within the black fault-related rock (scalebar represents $1 \mathrm{~mm}$ ) at $3,187.5 \mathrm{~m}$ MD; c pyrite framboid within fine-grained clayey gouge of the SDZ at 3,197.4 m MD; d conglobulated fault gouge with distorted vein patterns of the SDZ near 3,197.7 m MD (scalebar represents 1 $\mathrm{mm}$ ) may suggest fluid saturation of fault gouge during shear; e rounded, altered, and clay-rimmed clasts embedded within finegrained groundmass within foliated fault gouge of the SDZ at 3,197.9 m MD; and f pyrite growth surrounded by isolated irregular zones of carbonaceous material within clay gouge of the CDZ near 3,299 m MD Note, depths are reported as measured core depths and require a depth correction for comparison to geophysical log data (see Zоваск et al. 2010)

textures, and mechanisms may form (or exist) along significant portions of the SAF, or along transform faults that reactivate or initiate within serpentinitebearing rocks.

The block-in-matrix rock units adjacent to the active fault strands identified at SAFOD (ZоBACK et al. 2010) record an apparent damage asymmetry of the active fault zone. Rocks that extend for $\sim 10 \mathrm{~m}$ southwest of the SDZ are characterized by smaller average clast sizes compared to $10 \mathrm{~m}$ northeast of the CDZ (Table 1), suggesting the SDZ may represent a more localized, evolved strand due to the presence of multiple generations of cataclasite, brecciation, and/or granular flow (CHESTER et al. 1993; SiBSON 1977). The CDZ strand may be the more active trace, as suggested by measurements of casing deformation within the fault zone that show that creep is more pronounced in the CDZ relative to the SDZ (JEPPSON et al. 2010; Zоваск et al. 2010).

Directly southwest of the SDZ, microstructures and fabric within the block-in-matrix and black faultrelated rock units display evidence for localized and distributed deformation (Table 1; Figs. 6, 7, 8, 9). Injection of granular material and fine particles into surrounding matrix coupled with brecciation (Fig. 4a) may occur in response to increased fluid pressures and natural hydraulic fracturing (UJIIE et al., 2007). From southwest to northeast across the SAF, following the deformation trend, the alteration pattern as estimated by the CIA for the analyzed samples is higher southwest of the SDZ and lower between the SDZ and CDZ, returning to higher values east of the CDZ trace (Tables 1 and 2). Several clasts entrained within the fault gouges have very low CIA values (Table 2) relative to all other samples. These values may not be representative due to the abundance of carbonate veins within some of the clast samples (BAHLBERg and Dobrzinski 2011). Fibrous calcite veins northeast of the $\mathrm{CDZ}$ and numerous microveins southwest of the SDZ (Figs. 4, 5; Table 1) suggest that localized fluctuations in fluid pressure along the shear zone boundaries. The abundance and clustering of veins, coupled with $\mathrm{S}$ - and Fe-oxide mineralization, and increases in TOC (Table 2), are evidence for potential interactions with reducing fluids and/or hydrocarbon-bearing fluids during fracture and fault slip (CовBOLD and RodRIGUES 2007; RODRIGUES et al. 2009).

Fractures observed here may have resulted from seismic slip and co-seismic fluid infiltration in the main SAF zone in the black- sheared and stained fault-related rocks, and include: slip localization, cataclasite, and intense brecciation, polished fracture surfaces and microfracturing. Evidence for repeated deformation in these rocks includes the presence of multiple layers of cataclasite and reworked cataclasite clasts and numerous cross-cutting vein sets, including the clasts with multiple veinlets in the cataclasite (Fig. 5). Similar black-stained intervals are also present locally in the block-in-matrix unit to the southwest of the SDZ, but they are not visible within the cored interval of the adjacent SDZ gouge. The black fault rock and injection-like structures in the SAFOD core may also represent material generated during brittle failure from rupture elsewhere along the fault that has fluidized and become subsequently entrained into the creeping portion of the fault (e.g., DAviES et al. 2012).

The TOC analyses indicate that at least some of the black-stained rocks that occur adjacent to, and within, the SDZ and CDZ are relatively rich in organic carbon, and locally reach petroliferous grades (Table 2; D. Kirschner written comm., 2011; Peters and CASSA 1994), supporting the interpretation that some migration of hydrocarbon-bearing fluids, possibly from a Great Valley source, has occurred along and into the active fault strands (BRADBURY et al. 2011). The black staining with injection-like morphology coupled with multi-phase calcite veins indicates that the mobilization of hydrocarbons and 

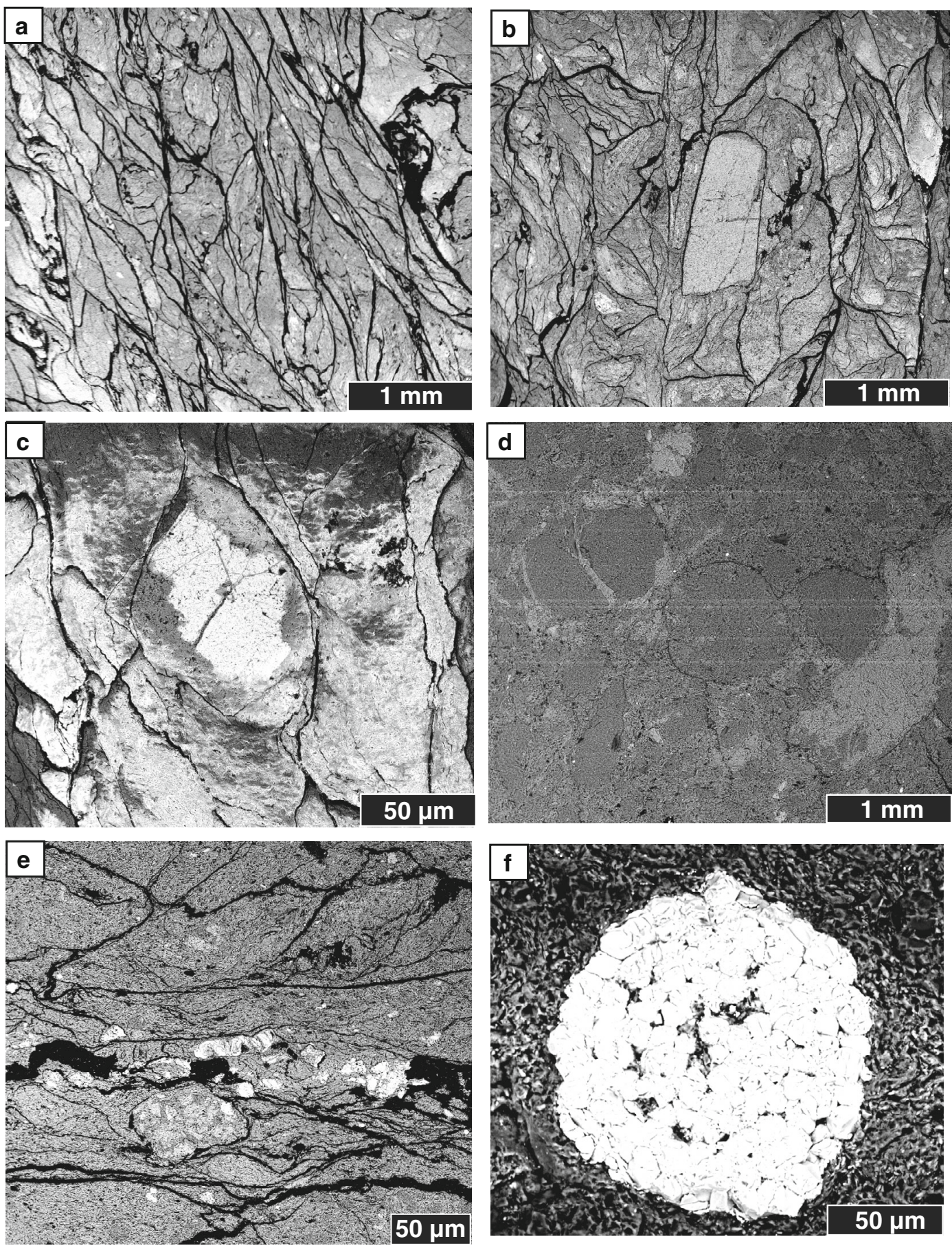

Figure 9

Scanning Electron Microscope images of exhumed shear zones within the Franciscan Formation: a pervasive foliated fabric exists to the submicron scale in sample in shear zone within Franciscan Formation near Goat Rock, CA; b isolated and altered clasts with varying degrees of roundness appear to "float" within fine to ultrafine-grained groundmass (see also Fig. 3; sample from shear zone within Franciscan Formation near Goat Rock); $\mathbf{c}$ alteration and/or clay transformation pattern appears to be associated with an interaction between the fracture system and the phacoidal-shaped clast, suggesting extensive fluid-rock reactions at this scale (sample from near Goat Rock, CA); d conglobulated texture and alteration of clasts within sheared rock of the Franciscan Formation near San Simeon, CA; e pyrite mineralization parallel to foliation direction and fracture surface, shear zone within Franciscan Formation, San Simeon, CA; and f spherule of pyrite within groundmass of shear zone within Franciscan Formation, near San Simeon, CA 
other fluids (liquids and/or gas) may be related to hydrofracture and transient changes in pore fluid pressure during slip (Holdsworth et al. 2011; Meneghini and Moore 2007; Mittempherger et al. 2011; Rowe et al. 2009). The presence of hydrocarbons in the fault zone rocks, the presence of carbonaceous residues in SAFOD samples, the strong petroliferous odor observed during handling of this portion SAFOD core from the CDZ, the shiny black appearance on some fracture surfaces, the carbon and oxygen isotopic signatures of veinlets from the core (KIRSCHNER et al. 2008), and the reports of hydrocarbons in the borehole after Phase II drilling (HENYEY et al. 2011) indicate elemental carbon \pm free hydrocarbons occurs within the SAF at depth. Mud gas analyses by WeIsberg and ERzinger (2011) showed evidence for the presence of hydrocarbonbearing fluids within the SAF and the presence of methane in the fault zone at 3,150-3,300 m MD. Natural gas and hydrocarbons were also encountered in the saline formation waters at SAFOD in 2005 and 2006, as discussed in HENYEY et al. (2011). Isotopic analyses of the mud gases indicate a contribution of mantle-derived source of the methane (WEISBERG and ERZINGER 2011) and standard Rock-Eval pyrolosis of pre-washed cuttings indicates that the rocks between 3,182 and $3,300 \mathrm{~m}$ contain terriginously derived thermally mature organic source rock in the dry to wet gas range (D. KIRSCHNER written comm. 2011). The $R_{o}$ (vitrinite reflectance) values from cuttings analyses range from 0.70 to 1.2 , well within the oil generation window and verging to the condensatewet gas window from Type III kerogen (D. KIRSCHNER, written comm. 2011).

The carbon/hydrocarbons could significantly influence geochemical alteration and slip processes along the SAF at SAFOD and be another key factor in contributing to fault zone weakness and slip localization, due to reduction of the coefficient of friction (BARTON and Lien 1974; Kohli and Zoback 2013; OонаSнI et al. 2011, 2012, 2013), an associated increase in pore pressure within the fault zone (Zоваск et al. 2010), or due to the presence of natural gas in the fine-grained gouge. Experimental results show that enrichment of carbon in fault zones may contribute to the development of lubricated and penetrative slip surfaces during deformation, similar to phyllosilicates, and thus enhance fault zone weakening mechanisms (КонLi and Zоваск 2013; OOHASHI et al. 2013).

Within the shear zones of the SDZ and CDZ (Figs. 4, 5), the intensity and variability of fabrics and alteration is high and includes S-C fabrics, breccias, multiple generations of cataclasite and reworked cataclasite, anastomosing phyllosilicaterich surfaces, clay-rimmed clasts, and elevated concentrations of $\mathrm{Fe}-\mathrm{Mg}$ oxides and sulfides relative to the surrounding host rocks. These characteristics suggest that distributed deformation and/or fluidassisted deformation occurs within the fault zone. Thin-section and SEM images also show that larger grains or clasts appear to have fines and matrix material adhered to their outer surface, suggesting the grains have rotated in an irregular, flow-like process throughout the gouge matrix (Fig. 8). Clay clast aggregates (BoutAREAud et al. 2010; Boullier et al. 2009; Colletini et al. 2009), clay-rimmed clast coatings, and the clay infillings between clasts or fragments are also features associated with fluidrelated processes and are consistent with textures observed during distributed deformation, thermal pressurization, and slip (BoutAREAUd et al. 2010; FAGERENG and SibSon 2010; Rowe et al. 2009). Geochemical analyses indicate a sharp increase in $\mathrm{Mg}$ oxide and Fe-oxide as silica content decreases. This trend is due to the abundance of smectite (saponite) in the scaly clay fault gouge (BRADBURY et al. 2011; LoCKNer et al. 2011; Moore and Rymer 2010; Moore and Rymer 2012). Saponite has an extremely low coefficient of friction $(\mu \approx 0.15-0.21)$ in laboratory studies and exhibits stable-sliding frictional behavior (CARPEnTER et al. 2009; CARPENTER et al. 2011; LOCKNER et al. 2011). Saponite is also commonly a fluid-assisted alteration product of serpentinite (BREARley 2006; ZolensKy et al. 1993) that exhibits plastic tenacity when hydrated and is brittle when dry (http://handbookofmineralogy.org). Lizardite \pm chrysotile compositions were identified in XRD and SEM (Bradbury et al. 2011; Moore and Rymer 2007, 2012; Morrow et al. 2010; Solum et al. 2007), and in thin-section, often in association with magnetite, pyrite, Ni-oxides, Cr-spinel, and/or garnet within both the SDZ and CDZ fault gouge matrix (Table 1; MoOre and Rymer 2012). The distinct mineral 
assemblage may indicate that fluids play an effective role of mobilizing and concentrating elements from a serpentinite-rich host-rock within the fault zone at the grain and slip-surface scale (Micklethwaite et al. 2010).

The CIA index ranges from low to moderate for the SDZ and CDZ (Figs. 4, 5), but this result may be a function of the abundance of Mg-rich and Fe-rich clay in the gouge matrix rather than $\mathrm{Al}$ and the abundance of relatively unaltered clasts. The LOI values may also be used as an indicator for fluid assisted alteration within the fault zone (Schulz and Evans 1998). Results for the samples tested show LOI is greatest in the CDZ region (Fig. 5), where a positive correlation to higher TOC values is also observed (Table 2).

The spatial variability in composition, alteration patterns, and textures spanning multiple scales of observation across the SAF in SAFOD supports the interpretation of mixed styles of deformation (FAGERENG and SiBSON 2010) or multiple deformation events, and supports the idea of a dynamic structural and permeability architecture. In-situ sampling across the $\mathrm{SAF}$ at $\sim 3 \mathrm{~km}$ depth at SAFOD demonstrates that the fault zone exhibits wide zones of pervasive deformation $(\sim 10-15 \mathrm{~m})$ separated by thin, anastomosing $(\sim 1-2 \mathrm{~m})$ foliated gouge zones (SDZ and $\mathrm{CDZ}$ ), numerous discrete slip surfaces (mm-cm thick) and a few entrained blocks ( $\sim 1-2 \mathrm{~m}$ in core length) that are only weakly deformed. These textures create a structural fabric that implies deformation processes related to aseismic creep and stable frictional sliding (Colletini et al. 2009; FAulKner et al. 2003; Reinen et al. 1991) with periodic seismic events. The presence of saponite coupled with the potential for a periodic influx of hydrocarbons within the active shear zones (Fig. 3f) may contribute to the formation of alteration products and/or foliated textures that promote additional weakening and deformation of the SAF (Colletini et al. 2009; 2011; Haines et al. 2009; LOCKNER et al. 2011; OOHTANI et al., 2013).

Based on the presence of serpentinite and highertemperature mineral assemblages, MOORE and RyMER (2012) and LOCKNER et al. (2011) also hypothesize that serpentinite is channelized up along the fault zone from depth and influences metasomatic reactions within the fault. This buoyancy-driven origin requires a source of fluids at depth and extensive physio-chemical interactions to bring material from depth. Similar fluid-assisted processes of transporting serpentinite-bearing rocks from depth have been documented in accretionary prism mélange deposits of the Franciscan Formation (CLOOS 1984) or through volumetric expansion associated with serpentinization (Page et al. 1999; Shervais et al. 2011).

We suggest that the fault-related rocks at SAFOD are strikingly similar to the serpentinite-bearing fault gouge and serpentinite mélanges within the faulted Franciscan Formation surface outcrops exposed at Goat Rock, San Simeon, and Nelson Creek (Figs. 3, 4, 5, 6, 7, 8,9 ; Table 1), and perhaps are charged with a range of hydrocarbons (Fig. 3f; Table 2; KIRSCHNER et al. 2008) due to enhanced permeability parallel to strike and reduced permeability perpendicular to the fault strands (WIERSBerg and ERzINGER 2011). Mélange fabrics may form through a variety of depositional and post-lithification processes, including tectonic folding and faulting, sedimentary and slope failure processes, and origin by vertically driven movements related to diapiric and/or volume expansion processes (BAILEY et al. 1964; Festa et al. 2010; RAYMOND, 1984; ShERVAis et al. 2011; Silver and BeUtNer 1980; VANNucchi et al. 2003; WaKabayashi and Dilek 2011). Each process is associated with distinct rock textures and/or compositions that may reflect the style of deformation (Cowan 1985; RAYMOND 1984; VANUCCHI et al. 2003). The fact that the SAFOD fault-related rocks appear nearly identical from the meso-scale to micro-scale to the mélange samples examined at the surface outcrops, suggests similar processes of origin such as: (1) block-in-matrix textures and scaly clay fabrics characterized by S-C surfaces; (2) sheared serpentinite clasts and blocks; (3) multiple phases and styles of calcite veining (Fig. 6d, e); (4) pyrite mineralization (aligned within interlayered fractures and as isolated framboids within the matrix (Figs. 6, 7, 8, 9); (5) fluidized and conglobulated textures within structural zones; and (5) alteration-rims surrounding numerous clasts entrained within the gouge or matrix materials (Fig. 7c).

A range of work has examined portions of the SAFOD core to evaluate the mechanical strength of these rocks. In general, workers agree that the SAF at the SAFOD site comprises a region of aseismic creep and small magnitude seismic rupture. Hypotheses that 
have been proposed to explain the creep and evidence for possible rupture include: (1) the presence of frictionally weak minerals within clay gouge such as talc, saponite, and/or serpentinite (CARPENTER et al. 2009; LOCKNER et al. 2011); (2) the presence of high density smectite-rich coatings $(<100 \mathrm{~nm}$ thick) on fracture surfaces interconnected at low angles (SCHLEICHER et al. 2010, 2012); (3) pressure-solution creep (Gratier et al. 2011); (4) record of transient migration of fluids into the fault zone (HicKMAN et al. 2004; MitTemphergher et al. 2011; WANG 2010); (5) generation of crush-origin psuedotachylytes (amorphous phases) within fault-related rocks (JANSSEN et al. 2010); and (6) development of multi-layered foliated fault gouge fabrics (Colletini et al. 2009; NiemeIJer et al. 2010). Our analyses of the SAFOD Phase 3 core fault-related rock show the actively creeping SAF at $\sim 3 \mathrm{~km}$ depth records a complex interplay of clay and serpentine mineral slip processes and fluid-rock interactions that evolve in both space and time (Table 1; Figs. 3, 4, 5, 6, 7, 8, 9). Amongst the fluids present within the fault are methane and free hydrocarbons, perhaps migrating parallel to the fault after the fault captured organic-bearing lozenges of organic-rich rock (D. Kirschner, pers. Comm., 2011; Wiersberg and ERZINGer 2011) and was also connected to a deeper source of mantle-derived methane (KenNedy et al. 1997; KhaRAKa et al. 1999; WiERSBERG and ERZINGER 2011; WAKABAYASHI and Dilek 2011). Thus the SAFOD site sampled a remarkably complex region of phyllosilicate-rich, serpentine-bearing sheared rock that experienced significant organic-rich and water-rich fluids that altered the deformed rocks over its history. The unique and complex fault composition of structure of the SAF encountered at SAFOD is a consequence of the large plate boundary fault cutting a range of heterogeneous lithologies. The material properties of these rocks \pm hydrocarbons and fluid-rock reactions, create slip surfaces that may undergo long-term slow slip punctuated by a narrow, focused seismic slip.

\section{Conclusions}

Whole-rock core from the creeping segment of the SAF at SAFOD and from exposed localities of exhumed, faulted serpentinite-bearing rocks provide insight into the mineralogical composition, geochemical alteration, and rock textures associated with active aseismic creep and the conditions that influence deformation and fluid (liquid and/or gas) interactions along the fault within the shallow crust. Sheared and/ or altered serpentinite, fine-grained foliated phyllosilicate-rich fault gouge, mineralization, hydrocarbons and carbonaceous material are all present within the fault zone at SAFOD, and may explain why aseismic creep occurs along the central segment of the SAF. Slow slip may develop as a result of pore fluid exchange and the alteration of frictional properties of the materials within the fault (KNIPE 1993; RUDNICKI and Rice 2006). The SAFOD core exhibits characteristics of rocks that have experienced high-pore fluid pressures during their development history; however, this cannot be definitively attributed to active slip. The inherent foliated textures may contribute to an aseismic deformation style, because they form an anastomosing network of weak phyllosilicate-rich surfaces. The SAFOD core shows that deformation within the active SAF at depth is highly variable spatially and temporally over relatively finite distances and from the meso-scale to the micro-scale. Direct sampling and analyses of SAFOD core reveals the SAF structure at depth and provides constraints on the physical and chemical processes and tectonic history associated with active SAF deformation.

\section{REFERENCES}

Allen, C.R. (1968), The tectonic environments of seismically active and inactive areas along the San Andreas Fault system, in Dickinson, W.R., and Grantz, A., eds., Proceedings of Conference on Geologic Problems of the San Andreas Fault: Standford, California, Stanford University Publication, 70-82.

ANDo, M. (2001), Geological and geophysical studies of the Nojima Fault from drilling: An outline of the Nojima Fault Zone Probe. Island Arc, 10, 3-4, 206-214.

Bahlberg, H. and Dobrzinski, N. (2011), A review of the Chemical Index of Alteration (CIA) and its application to the study of Neoproterozoic glacial deposits and climate transitions, 81-92, in Arnaud, E., Halverson, G.P., and Shields, G.A. (Eds.), The geological record of Neoproterozoic glaciations: Geological Society Memoir No. 36.

BALL, D.F. (1964), Loss-on-Ignition as an estimate of organic matter and organic carbon in non-calcareous soils. Journal of Soil Science, 15, 1, 84-92. 
Bailey, E.H., Irwin, W.P., and Jones, D.L. (1964), Franciscan and related rocks, and their significance in the geology of western California. California Division of Mines Bulletin 183, 177p.

Barth, N.C., Boulton, C., Carpenter, B.M., Batt, G.E., and Toy, V.G., (2013), Slip localization on the southern Alpine Fault, New Zealand. Tectonics, doi:10.1002/tect.20041.

Barton, N., Lien, R., and Lunde (1974), Engineering classification of rocks masses for the design of tunnel support. Rock Mechanics, 6, 189-236.

Blake, M. C., JR., Graymer, R. W., and Stamski, R. E. (2002), Geologic map and map database of western Sonoma, northernmost Marine, and southernmost Mendocino counties, California, U. S. Geological Survey Map MF-2402.

Boullier, A.M., Yeh, E.C., Boutareeaud, S., Song, S.R., and Tsai, C.H. (2009), Microscale anatomy of the 1999 Chi Chi earthquake fault zone. Geochemistry, Geophysics, Geosystems, 10, 3, 1-25, doi:10.1029/2008GC002252.

Boutareaud, S., Calugaru, D.G., Han, R., Fabbri, O., Mizoguchi, K., Tsutsumi, A., and Sнimamoto, T. (2008), Clay-clast aggregates: A new textural evidence for seismic fault sliding? Geophysical Research Letters, v. 35, L05302, doi:10.1029/ 2007 GL032554.

Boutareaud, S., Boullier, A., Andreani, M., Calugaru, D.G., Beck, P., Song, S.R., and Shimamoto, T.(2010), Clay clast aggregates in gouges: New textural evidence for seismic faulting. Journal of Geophysical Research, 115, B02408, doi:10.1029/ 2008JB006254.

Bradbury, K. K., Barton, D. C., Solum, J. G., Draper, S. D., Evans J. P. (2007), Mineralogic and textural analyses of drill cuttings from the San Andreas Fault Observatory at Depth (SAFOD) boreholes: Initial interpretations of fault zone composition and constraints on geologic models. Geosphere, 3, 299-318.

Bradbury, K.K., Evans, J., Lowry, A.R., and Jeppson, T.(2009), Integration of geology and borehole geophysics to characterize rock properties at the San Andreas Fault Observatory at Depth (SAFOD) site, near Parkfield, CA, RMGSA Section $61^{\text {st }}$ Meeting, Geol. Soc. Amer. Abs. Prog., 41, 6, 13.

Bradbury, K.K., Evans, J.P., Chester, J.S., Chester, F.M., and KIRSCHNER, D.K. (2011), Lithology and internal structure of the San Andreas fault at depth based on characterization of Phase 3 whole-rock core in the San Andreas Fault Observatory at Depth (SAFOD) borehole. Earth and Planetary Science Research Letters, 310, 1-2, 131-144.

Brearley, A.J., The action of Water, In Meteorites and the early solar system II (ed. Lauretta, D., McSween Jr, H.Y., and Leshin, L.), (Arizona University Press 2006), pp. 587-562.

Brodsky, E.E., Rowe, C.D., Meneghin, E., and Moore, J.C. (2009), A geological finger print of low-viscosity fault fluids mobilized during an earthquake. Journal of Geophysical Research, 114 B01303, doi:10.1029/2008JB005633.

Caine, J.S., Evans, J. P., and Forster, C.B. (1996), Fault zone architecture and permeability structure. Geology, 24, no. 11, p. 1025-1028, doi:10.1130/0091-7613.

CAine, J.S., Bruhn, R.L., and Forster, C.B. (2010), Internal structure, fault-related rocks, and inferences regarding deformation, fluid flow, and mineralization in the seisomgenic Stillwater normal fault, Dixie Valley, Nevada J. of Struct. Geol.,32, 11, 1576-1589, doi:10.1016/j.jsg.2010.03.004.

Carpenter, B.M., Marone, C., and SAFFer, D.M. (2009), Frictional behavior of materials in the 3D SAFOD volume. Geophysical
Research Letters, 36, L05302, doi:10.1029/2008GL039990, 2009.

Carpenter, B.M., Marone, C., and SafFer, D.M. (2011), Weakness of the San Andreas Fault revealed by samples from the active fault zone. Nature Geoscience, 4, p. 251-254, doi:10.1038/ NGE01089.

Chester, F.M., and Logan, J.M. (1986), Implications for mechanical properties of brittle faults from observation of the Punchbowl fault zone, California. Pure and Applied Geophysics, 124, 79-106, doi:10.1007/BF00875720.

Chester, F. M., Evans, J. P., and Biegel, R. L. (1993), Internal structure and weakening mechanisms of the San Andreas Fault. Journal of Geophysical Research, 98,. 771-786.

CLoos, M. (1984), Flow melanges and the structural evolution of accretionary wedges. Geological Society of America Special Paper 198, 71-79.

Cobbold, P.R., And Rodrigues, N. andRodrigues, N. (2007), Seepage forces, important factors in the formation of horizontal hydraulic fractures and bedding-parallel fibrous veins ("beef" and "cone-in-cone"). Geofluids, 7, p. 313-332, doi:10.1111/j. 1468-8123.2007.00183.x.

Coleman, R.G. (1996), New Idria: A land management dilemma. Environmental and Engineering Geoscience, 2, 1, 9-22.

Colletini, C., Niemeijer, A., Viti, C., and Marone, C. (2009), Fault zone fabric and fault weakness. Nature, 462, 907-910, doi:10. 1038/nature08585.

Collettini, C., Niemeijer, A.,Viti, C., Smith, S.A.F., and Marone, C. (2011), Fault zone fabric and fault weakness Earth and Planetary Science Letters, 311, 316-327, doi:10.1016/j.epsl.2011. 09.020.

Cornet, F.H., Doan, M.L., Bernard, P., Moretti, I., and Borm, G. (2004), Drilling through the active Aigion Fault: The AIG10 well observatory. Geoscience 336, 395-406, doi:10.1016/j.crte.2004. 02.002 .

Cowan, D.S. (1978), Origin of blue-schist bearing chaotic rocks in the Franciscan Complex, San Simeon, California Geological Society of America Bulletin, 89, 1415-1423.

Cowan, D.S. (1985), Structural styles in Mesozoic and Cenozoic mélanges in the western Cordillera of North America. Geological Society of America Bulletin, 96, 451-462, doi:10.1130/00167606(1985)96<451:SSIMAC $>2.0 . C O ; 2$.

Cowan, D.S. (1999), Do faults preserve a record of seismic slip: A field geologist's opinion. J. of Struct. Geol., 21, 995-1001.

Davies, T.R.H, McSAVEney, M.J., and Boulton, C.J. (2012), Elastic strain energy release from fragmenting grains: Effect on fault rupture. J. of Struct. Geol., 38, 265-267.

DibbleE, T.W. (1971), Geologic maps of seventeen 15-minute quadrangles along the San Andreas Fault in the vicinity of King City, Coalinga, Panoche Valley, and Paso Robles, California: U.S. Geological Survey Open-File Report 71-87, scale 1:62,500.

Dickinson, W.R. (1966), Table Mountain serpentinite extrusion in California Coast Ranges. Geological Society of America Bulletin, 77 451-472, doi:10.1130/00167606(1966)77[451:TMSEIC]2.0.CO;2.

Ellsworth, W.L., and Malin, P. E., Deep rock damage in the San Andreas Fault revealed by P- and S-type fault-zone guided waves, In Geology of the earthquake source: a volume in honour of Rick Sibson (ed. Fagereng, A., Toy, V., and Rowland, J.) (Geol. Soc. of London 2011) pp. 39-53.

Evans, J.P., and F.M. Chester (1995), Fluid-rock interaction in faults of the San Andreas system: Inferences from San Gabriel 
fault-related rock geochemistry and microstructures. Journal of Geophysical Research, 100, (B7), 13007-13020.

FAGERENG A., and Sibson, R.H. (2010), Melange rheology and seismic style. Geology, 38, 8, 751-754, doi:10.1130/G30868.1.

FAgereng A., and Toy V., Geology of the earthquake source: an introduction, In Geology of the earthquake source: a volume in honour of Rick Sibson (ed. Fagereng, A., Toy, V., and Rowland, J.) (Geol. Soc. of London 2011), pp. 1-16.

FaulKNeR, D.R., Lewis, A.C., and RutTer, E.H. (2003), On the internal structure and mechanics of large strike-slip fault zones: Field observations of the Carboneras Fault in southeastern Spain. Tectonophysics, 367, 235-251, doi:10.1016/S0040-1951(03)00134-3.

Festa, A., Pini, G., Dilek, Y., and Codegone, G. (2010), Melanges and mélange-forming processes: A historical overview and new concepts. International Geology Review, 52, 10-12, 1040-1105, doi:10.1080/00206810903557704.

Gratier, J.P., Richard, J., Renard, R., Mittempergher, S., Doan, M.L., Di Toro, G., Hadizadeh, J., and Boullier, A.M. (2011), Aseismic sliding of active faults by pressure solution creep: Evidence from the San Andreas Fault Observatory at Depth: Geology, 39, 12, 1131-1134, doi:10.1130/G32073.1.

Haines, S. H., van der Pluijm, B.A., Ikari, M.J., Saffer, D.M., and Marone, C. (2009), Clay fabric intensity in natural and artificial fault gouges: implications for brittle fault zone processes and sedimentary basin clay fabric evolution. Journal of Geophysical Research, 114, B05406, doi:10.1029/2008JB005866.

Heermance, R.V., Shipton, Z.K., and Evans, J.P. (2003), Fault structure control on fault slip and ground motion during the 1999 rupture of the Chelungpu Fault, Taiwan: Bulletin of the Seismological Society of America, 93, 1034-1050.

Henyey, T., Henfling, J., Linde, A., Steidl, J., and De Paolo, D.(2011), Report of the SAFOD Engineering Subcommittee of the Advisory Committee for Geosceinces, March 30, 2011; last accessed Nov 23, 2011, http://www.earthscope.org/es_doc/ reports/safodreport.pdf.

Hickman, S., Zoback, M.D., and Ellsworth, W. (2004), Introduction to special section: Preparing for the San Andreas Fault Observatory at Depth. Geophysical Research Letters, 31, L12S01, doi:10.1029/2004GL020688.

Hickman, S., Zoback, M., Ellsworth, W., Boness, N., Malin, P., RoEcker, S., and Thurber, C. (2007), Structure and properties of the San Andreas Fault in central California: Recent results from the SAFOD experiment Scientific Drilling, Special Issue 1, 29-32, doi:10.2204/iodsd.s01.2007.

Hirono, T., Yeh, E.-C., Lin, W., Sone, H., Mishima, T., Soh, W., Hashimoto, Y., Matsubayashi, O., Aoike, K., Ito, H., Kinoshita, M., Murayama, M., Song, S.-R., Ma, J.-H., Wang, C.-Y., Tsai, Y.-B., Kondo, T., Nishimura, M., Moriya, S., Tanaka, T., Fujiki, T., Maeda, L., Muraki, H., Kuramoto, T., Sugiyama, K., SuGaWARA, T. (2007), Nondestructive continuous physical property measurements of core samples recovered from hole B, Taiwan Chelungpu-Fault Drilling Project, Journal of Geophysical Research, 112, B07404, doi:10.1029/2006JB004738.

Hirth, G., and Guillot, S. (2013), Rheology and tectonic significance of serpentinite, Elements, 9, 107-113.

Holdsworth, R.E., van Diggelen, E.W.E., DE Bresser, J.H.P., WALKER, R.J., and BowEN, L. (2011), Fault-related rocks from the SAFOD core samples: Implications for weakening at shallow depths along the San Andreas Fault, California. J. of Struct. Geol., 33, 132-144, doi:10.1016/j.jsg.2010.11.010.
Hole, J.A., Ryberg, T., Fuis, G.S., Bleibinhaus, F., and Sharma, A.K. (2006), Structure of the San Andreas fault zone at SAFOD from a seismic refraction survey. Geophysical Research Letters, 33, doi:10.1029/2005GL025194.

Hsü, K.J. (1969), Principles of mélanges and their bearing on the Franciscan-Knoxville Paradox. Geological Society of America Bulletin, 79, 1063-1074, doi:10.1130/0016-7606(1968)79.

IRWIN W., and BARNES, I. (1975), Effect of geologic structure and metamorphic fluids on seismic behavior of the San Andreas Fault system in central and northern California. Geology, 3, 12, 713-716, doi:10.1130/0091-7613.

Janssen, C., Wirth, R., Rybacki, R., Naumann, E., Kemnitz, H., Wenk, H.-R., and Dresen, G. (2010), Amorphous material in SAFOD core samples (San Andreas Fault): Evidence for crush origin pseudotachelytes? Geophysical Research Letters, 37, L01303, doi:10.1029/2009GL040993.

Janssen, C., Kanitpanyacharoen, W., Wenk, H. R., Wirth, R., Morales, L., Rybacki, R., Kienast, M., and Dresen, G. (2012), Clay fabrics in SAFOD core samples. J. of Struct. Geol., 43, 118-127.

Jeppson, T.N., Bradbury, K.K., and Evans, J.P.(2010), Geophysical properties within the San Andreas Fault Zone at the San Andreas Fault Observatory at Depth and their relationships to rock properties and fault zone structure. Journal of Geophysical Research, 115, B12423, doi:10.1029/2010JB007563.

Kennedy, B. M., Kharaka, Y. K., Evans, W. C., Ellwood, A., De Paolo, D. J. (1997), Mantle fluids in the San Andreas fault system. California, Science, 278, 1278-1281.

Kharaka, Y.K., Thordsen, J.J., Evans, W. C., Kennedy, B. M. (1999), Geochemistry and hydromechanical interactions of fluids associated with the San Andreas fault system, California. American Geophysical Union Monograph 113 129-148.

KNIPE, R.J. (1993), The influence of fault zone processes and diagenesis on fluid flow, in Horbury, A.D., and Robinson, A.G., eds., Diagenesis and Basin Development: Americal Association of Petroleum Geologists, Studies in Geology, v. 36, p. 135-148.

KnIPE, R.J., Jones, G., Fisher, Q.J. (1998), Faulting, fault sealing and fluid flow in hydrocarbon reservoirs: An introduction: Geological Society of London Special Publication, v. 147, p. vii-xxi.

Kohl, A. H., and Zоваск, M.D. (2013), Frictional properties of shale reservoir rocks: Journal of Geophysical Research. Solid Earth, 118, 5109-5125, doi:10.1002/jgrb.50346.

Lockner, D.A., Morrow, C., Moore, D., and Hickman, S. (2011), Low strength of deep San Andreas fault gouge from SAFOD core. Nature, 472, 82-85, doi:10.1038/nature09927.

Marone, C., and Richardson, E. (2010), Learning to read fault-slip behavior from fault-zone structure Geology, 38, 767-768, doi:10. 1130/focus082010.1.

McPhee, D.K., R. C. Jachens, and Wentworth, C. M., 2004, Crustal structure across the San Andreas fault at the SAFOD site from potential field and geologic studies. Geophys Res. Let. 31, L12S03.

Medley, E.W., and Goodman, R.E. (1994), Estimating the block volumetric proportions of mélanges and similar block-in-matrix rocks (bimrocks), in Nelson, P.P., and Laubauch, S.E., eds., Rock mechanics models and measurement challenges from industry: Proceedings, North American Rock Mechanics Symposium, $1^{\text {st }}$, Austin, Texas, May 1994, p. 851-858.

Meneghini, F., and Moore, J.C. (2007), Deformation and hydrofracture in a subduction thrust at seismogenic depths: The Rodeo 
Cove thrust zone, Marin Headlands, California. Geological Society of America Bulletin, 119, 1-2, 174-183.

Micklethwaite, S., Sheldon, H.A., BaKer, T. (2010), Active fault and shear processes and their implications for mineral deposit formation and discovery. J. of Struct. Geol., 32, 2, 151-165.

Mittempergher, S., Toro, G.D., Gratier, J.P., Hadizadeh, J., and Sмiтh, S. (2011), Evidence of transient increases of fluid pressure in SAFOD Phase III Cores. Geophysical Research Letters, 38, L03301, doi:10.1029/2010GL046129.

Molnar, P., AND DAYEM, K.E. (2010), Major intracontinental strikeslip faults contrasts in lithospheric strength. Geosphere, 6, 444-467.

Moore, D., and Lockner,D. (2013), Chemcial controls on fault behavior: Weakening of serpentinite sheared against quartzbearing rocks and its significance for fault creep in the San Andreas system, Journal of Geophysical Research, 118, doi:10. 1002/jgrb.50140.

Moore, D.E., and Rymer, M.J. (2012), Correlation of clayey gouge in a surface exposure of serpentinite in the San Andreas Fault with gouge from the San Andreas Fault Observatory at Depth (SAFOD). J. of Struct. Geol., 38, 51-60, doi:10.1016/j.jsg.2011. 11.014.

Moore, D.E., and Rymer, M.J. (2010), Metasomatic origin of fault gouge comprising the two actively creeping strands at SAFOD: American Geophysical Union, Fall Meeting, San Francisco, California, Abstract T41A-2105.

Moore, D.E., and Rymer, M.J. (2009), Clay rich fault gouge identified in serpentinite from the San Andreas Fault zone at Nelson Creek, Monterey County, California: American Geophysical Union, Fall Meeting, Abstract T53C-1599.

Moore, D.E., and Rymer, M.J. (2007), Talc-bearing serpentinite and the creeping section of the San Andreas Fault. Nature, 448, 795-797, doi:10.1038/nature06065.

Moore, D., Lockner, D., Shengli, M., Summers, R., and Byerlee, J.D. (1997) Strengths of serpentinite gouges at elevated temperatures. Journal of Geophysical Research, 102, B7, 14,787-14,801.

Morrow, C.A., Lockner, D.A., Moore, D.E., and Hickman, S. (2010), SAFOD core reveals low strength of deep San Andreas Fault gouge and provide explanation for low heat flow in creeping section of fault: American Geophysical Union, Fall Meeting, San Francisco, California, Abstract T52B-05.

Nadeau, R. M., Michelini, A., Urhammer, A., Dolenc, D., and McEvilly, T. V. (2004), Detailed kinematics, structure and recurrence of microseismicity in the SAFOD target region. Geophysical Research Letters, 31, 15, L12S08, doi:10.1029/ 2003GL019409.

Niemeijer, A., Marone, C., and Elsworth, D. (2010), Fabric induced weakness of tectonic faults, Geophysical Research Letters, 37, L03304, doi:10.1029/2009GL041689.

Nesbitt, H.W., and Young, G. M. (1982), Early Proterozoic climates and plate motions inferred from major element chemistry of lutites. Nature, 299, 715-717, doi:10.1038/299715a0.

Ohtani, T., Fujimoto, K., Ito, H., Tanaka, H., Tomida, N., and Higuchi, T.(2000), Fault-related rocks and past to recent fluid characteristics from the borehole survey of the Nojima fault ruptured in the 1995 Kobe earthquake, southwest Japan: Journal of Geophysical Research.. 105, 16161-16171, doi:10.1029/ 2000JB900086.

Page, B., De Vito, L.A., and Coleman, R.G. (1999), Tectonic emplacement of serpentinite southeast of San Jose, California. International Geology Review, 41, 491-505.
Peters, K.E., and Cassa, M.R. (1994), Applied source rock geochemistry, in Magoon, L.B., and Dow, W.G., eds., The petroleum system-From source to trap: Tulsa, Oklahoma: American Association of Petroleum Geologists Memoir, v. 60, p. $93-117$.

Oоhashi, K., Hirose, T., and Shimamoto, T. (2011), Shear-induced graphitization of carbonaceous materials during seismic fault motion: experiments and possible implications for fault mechanics. J. of Struct. Geol., 33, 1122-1134, doi:10.1016/j/jsg/ 2011.01.007.

Oohashi, K., Hirose, T., Kobayashi, K., and Shimamoto, T. (2012), The occurrence of graphite-bearing fault rocks in the Atotsugawa fault system, Japan: origins and implications of fault creep. J. of Struct. Geol., 38, 39-50, doi:10.1016/j/jsg/2011.10.011.

Oohashi, K., Hirose, T., and Shimamoto, T. (2013), Graphite as a lubricating agent in fault zones: an insight from low- to highvelocity friction experiments on a mixed graphite-quartz gouge. Journal of Geophysical Research, 118, 2067-2084, doi:10.1002/ jgrb.50175.

RAYMOND, L.A., ed. (1984), Melanges: Their nature, origin, and significance: Geological Society of America Special Paper 198, p. 170.

Reinen, L.A., WeEks, J.D., and Tullis, T.E. (1991), The frictional behavior of serpentinite: Implications for aseismic creep on shallow crustal faults. Geophysical Research Letters, 18, 10, 1921-1924.

ReInen, L.A. (2000), Seismic and aseismic slip indicators in serpentinite gouge. Geology, 28, 135-138, doi:10.1130/00917613(2000)28<135:SAASII >2.0.CO; 2 .

Rodrigues, N., Cobbold, P.R., LøSeth, H., and Ruffet, G. (2009), Widespread bedding-parallel veins of fibrous calcite ("beef") in a mature source rock (Vaca Muerta Fm, Neuquén Basin, Argentina): Evidence for overpressure and horizontal compression. Journal of the Geological Society of London, 166, 4, 695-709, doi:10.1144/0016-76492008-111.

Rowe, C.D., Meneghini, F., and Moore, J.C. (2009), Fluid-rich damage zone of an ancient out-of-sequence-thrust, Kodiak Islands, Alaska. Tectonics, 28, TC1006, doi:10.1029/ 2007TC002126.

RudNicki, J.W., and Rice, J.R. (2006), Effective normal stress alteration due to pore pressure changes induced by dynamic slip propagation on a plane between dissimilar materials. Journal of Geophysical Research, 111, B10308, doi:10.1029/2006 JB004396.

Rybacki, E., Janssen, C., Wirth, R., Wenk, R., and Dresen, G. (2010), Low-temperature deformation in calcite veins of SAFOD core samples (San Andreas Fault)-microstructural analysis and implications of fault strength: American Geophysical Union, Fall Meeting, San Francisco, California, Abstract T52B-07.

Rymer, M.J., Catchings, R.D., and Goldman, M.R. (2003), Structure of the San Andreas Fault zone as revealed by surface geologic mapping and high-resolution seismic profiling near Parkfield, California. Geophysical Research Abstracts, 5, 13523.

Schleicher, A. M., van der Pluijm, B. A., Solum, J. G., Warr, L. N. (2006), Origin and significance of clay-coated fractures in mudrock fragments of the SAFOD borehole (Parkfield, California). Geophysical Research Letters 33.16, L16313.

Schleicher, A.M., van Der Pluijm, B.A., and Warr, L.N. (2010), Nanocoatings of clay and creep of the San Andreas Fault at Parkfield, California. Geology, 38, 667-670, doi:10.1130/ G31091.1. 
Schleicher, A.M., van der Pluijm, B.A., and Warr, L.N. (2012), Chlorite-smectite clay minerals and fault behavior: new evidence from the San Andreas Fault Observatory at Depth (SAFOD) core. Lithosphere, 4, 209-220, doi:10.1130/L158.1.

Schulz, S.E., and Evans, J. (1998), Spatial variability in microscopic deformation and composition of the Punchbowl Fault, southern California: Implications for for mechanisms, fluid-rock interaction, and fault morphology. Tectonophysics, 295, 223-244.

Schulz, S.E., and Evans, J., (2000), Mesoscopic structure of the Punchbowl fault, southern California, and the geological and geophysical structure of active faults. J. of Struct. Geol., 22, 913-930, doi:10.1016/S0191-8141(00)00019-5.

Scott, R.J., MefFre, S., Woodhead, J., Gilbert, S., Berry, R., and EmsBo, P. (2009), Development of framboidal pyrite during diagenesis, low-grade regional metamorphism, and hydrothermal alteration. Society of Economic Geologists, 104, 1143-1168, doi:10.2113/gsecongeo.104.8.1143.

Shervais, J., Kolesar, P., and Andreasen, K. (2004), Field and chemical study of serpentinization-Stonyford, California: Chemical fluxes and mass balance, in Ernst, W.G., ed., Serpentine and serpentinites: Mineralogy, petrology, geochemistry, ecology, geophysics, and tectonics (a tribute to Robert G. Coleman): Columbia, Maryland, Bellwether Publishing Ltd., International Book Series, 8, 452- 474.

Shervais, J., Choi, S., Sharp, W., Ross, J., Zoglman-Schuman, M., and Mukasa, S. (2011), Serpentinite matrix mélange: Implications of mixed provenance for mélange formation. Geological Society of America Special Paper 480, 1-30.

Shipton, Z., and Cowie, P. (2001), A conceptual model for the origin of fault damage zone structures in high-porosity sandstone. J. of Struct. Geol., 25, 333-344.

SibSON, R.H. (1977), Fault-related rocks and fault mechanisms. Journal of the Geological Society of London, 133, 191-213.

SiBson, R. H. (1989), Earthquake faulting as a structural process. J. of Struct. Geol., 11, 1-14.

Sibons, R.H. (2003), Thickness of the seismic slip zone. Bulletin Seismological Society of America, 93, 1169-1178.

Sims, J.D. (1990), Geologic map of the San Andreas Fault in the Parkfield 7.5-minute Quadrangle, Monterey and Fresno counties, California: U.S. Geological Survey Miscellaneous Field Studies Map MF-2115.

Sims, J.D. (1988), Geologic map of the San Andreas fault zone in the Cholame Valley and Cholame Hills quadrangles, San Luis Obispo and Monterey counties, California: U.S. Geological Survey Miscellaneous Field Studies Map MF-1995.

Silver, E.A., and Beutner, E.C. (1980), Melanges-Penrose Conference report. Geology, 8, 32-34.

Singleton, J. S., Cloos, M. (2012), Kinematic analysis of melange fabrics in the Franciscan Complex near San Simeon, California; evidence for sinistral slip on the Nacimiento fault zone? Lithosphere, 5 179-188.

Solum, J.G., Hickman, S., Lockner, D., Tembe, S., Evans,J., DraPer, S.D., Barton, D.C., Kirschner, D., Chester, J., Chester, F., van der Pluijm, B., Schleicher, A., Moore, D., Morrow, C., Bradbury, K., Calvin, W., and Wong, T. (2007), San Andreas Fault Zone mineralogy, geochemistry, and physical properties from SAFOD cuttings and core. Scientific Drilling Special Issue 1, 64-67.

Solum, J.G., Hickman, S.H., Lockner, D.A., Moore, D.E., van Der Pluijm, B.A., Schleicher, A.M., and Evans, J. (2006),
Mineralogical characterization of protolith and fault-related rocks from the SAFOD Main Hole. Geophysical Research Letters, 33, doi:10.1029/2006GL027285.

Tanaka, H., Wang, C.Y., Chen, W.M., Arito, S., Kotaro, U., Ito, H., and Masataka, A. (2002), Initial science report of shallow drilling penetrating into the Chelungpu fault zone, Taiwan. Terrestrial, Atmospheric, and Oceanic Sciences, 13, 227-251.

Thayer, M., AND R. Arrowsmith, 2005, Fault zone structure of Middle Mountain, Central California, EOS Trans. AGU, 86(52), Fall Meet. Suppl., T21A0458.

Thurber, C., Roecker, S., Zhang, H., Baher, S., and Ellsworth, W. (2004), Fine-scale structure of the San Andreas Fault Zone and location of the SAFOD target earthquakes. Geophys. Res. Lett., 31, L12S02, doi:10.1029/2003GL019398.

Thurber, C., Zhang, F., Waldhauser, J., Hardebeck, J., Michael, A., and Eberhart-Phillips, D. (2006), Three-dimensional compressional wavespeed model, earthquake relocations, and focal mechanisms for the Parkfield, California region. Bull. Seismol. Soc. of Am., 96, S38-S49.

Titus, S.J., DeMets, C., and Tikoff, B. (2006), Thirty-five-year creep rates for the creeping segment of the San Andreas Fault and the effects of the 2004 Parkfield earthquake: Constraints from alignment arrays, continuous global positioning system, and creepmeters. Bull. Seismol. Soc. of Am., 96, S250-S268, doi:10. 1785/0120050811.

Tobin, H., and Kinoshita, M. (2006), NanTroSeize: The IODP Nankai Trough Seismogenic Zone Experiment. Scientific Drilling, 2, 23-27, doi:10.2204/iodp.sd.2.06.2006.

Townend, J., Sutherland, R., and Toy, V. (2009), Deep drilling fault project-Alpine Fault Zone. Scientific Drilling, 8, p. 75-82.

Ujie, K., Yamaguchi, A., Kimura, G., and Toh, S. (2007), Fluidization of granular material in a subduction thrust at seismogenic depths. Earth and Planetary Science Letters, 259, 307-318, doi:10.1016/j.eps1.2007.04.049.

Vannucchi, P., Maltman, A., Bettelli, G., and Clennell, B. (2003), On the nature of scaly fabric and scaly clay. J. Struct. Geol., 25, 673-688, doi:10.1016/S0191-8141(02)00066-4.

Wakabayashi, J., and Dilek, Y. (2011), Introduction: Characteristics and tectonic settings of mélanges, and their significance for societal and engineering problems Geol. Soc. of Am. Special Paper 480, v-ix.

WANG, K. (2010), Finding faults in fault zones: Science, 9, 152-153.

WibBerley, C.A.J., Yielding, G., and Di Toro, G., Recent advances in the understanding of fault zone structure, In The internal structure of fault zones: Implications for mechanical and fluidflow properties, (eds. Wibberley, C.A.J., Kurz, W., Imber, J., Holdsworth, R.E., and Coletinni, C) (Geological Society of London Special Publication 299 2008), pp. 5-33.

Wiesberg, T., Erzinger, J. (2011), Chemical and isotope compositions of drilling mud gas from the San Andreas Fault Observatory at Depth (SAFOD) borehole: Implications on gas migration and the permeability structure of the San Andreas Fault Chemical Geology, 284, 148-159.

Zoback, M.D., Hickman, S., and Ellsworth, W. (2005) Overview of SAFOD Phases 1 and 2: Drilling, sampling and measurements in the San Andreas Fault zone at seismogenic depth. EosTrans. AGU, 86 (52), Fall Meet. Suppl., Abstract T23E-01.

Zoback, M.D., Hickman, S., and Ellsworth, W.E., The role of fault zone drilling, In Treatise to Geophysics: (ed. Schubert, G.) (New York, Elseveir, 2007), pp. 649-674. 
Zoback, M.D., Hickman, S.H., and Ellsworth W.E. (2010), Scientific drilling into the San Andreas Fault Zone, Eos Transactions. American Geophysical Union, 91, 197-204.

Zoback, M.D., Hickman, S.H., and Ellsworth W.E. (2011) Scientific drilling into the San Andreas Fault Zone-An overview of the first five years, Scientific Drilling, 11, 14-28.
Zolensky, M.E., Barrett, R., and Browning, L. (1993), Mineralogy and composition of matrix and chondrule rims in carbonaceous chondrites, Geoch. et Cosmo. Acta, 57, 3123-3148.

(Received September 7, 2013, revised July 2, 2014, accepted July 5, 2014) 